\title{
Polysaccharides as Edible Films and Coatings: Characteristics and Influence on Fruit and Vegetable Quality-A Review
}

\author{
Anna Kocira ${ }^{1, *(\mathbb{D})}$, Katarzyna Kozłowicz ${ }^{2} \mathbb{D}$, Katarzyna Panasiewicz ${ }^{3} \mathbb{D}$, Mariola Staniak ${ }^{4} \mathbb{D}$, Ewa Szpunar-Krok ${ }^{5} \mathbb{D}$ \\ and Paulina Hortyńska ${ }^{6}$
}

check for

updates

Citation: Kocira, A.; Kozłowicz, K.; Panasiewicz, K.; Staniak, M.;

Szpunar-Krok, E.; Hortyńska, P.

Polysaccharides as Edible Films and

Coatings: Characteristics and

Influence on Fruit and Vegetable

Quality-A Review. Agronomy 2021,

11, 813. https://doi.org/10.3390/

agronomy11050813

Academic Editor: Vittorio Farina

Received: 23 March 2021

Accepted: 19 April 2021

Published: 21 April 2021

Publisher's Note: MDPI stays neutral with regard to jurisdictional claims in published maps and institutional affiliations.

Copyright: (c) 2021 by the authors. Licensee MDPI, Basel, Switzerland. This article is an open access article distributed under the terms and conditions of the Creative Commons Attribution (CC BY) license (https:/ / creativecommons.org/licenses/by/ $4.0 /)$.
1 Institute of Agricultural Sciences, State School of Higher Education in Chełm, Pocztowa 54, 22-100 Chełm, Poland

2 Department of Biological Bases of Food and Feed Technologies, University of Life Sciences in Lublin, Głeboka 28, 20-612 Lublin, Poland; katarzyna.kozlowicz@up.lublin.pl

3 Department of Agronomy, Faculty of Agronomy and Bioengineering, Poznań University of Life Sciences, Dojazd 11, 60-632 Poznań, Poland; katarzyna.panasiewicz@up.poznan.pl

4 Department of Forage Crop Production, Institute of Soil Science and Plant Cultivation-State Research Institute, Czartoryskich 8, 24-100 Puławy, Poland; staniakm@iung.pulawy.pl

5 Department of Crop Production, University of Rzeszow, Zelwerowicza 4, 35-601 Rzeszow, Poland; szpunar-krok@wp.pl

6 Department of Landscape Architecture, Faculty of Horticulture and Landscape Architecture, University of Life Sciences in Lublin, Głeboka 28, 20-612 Lublin, Poland; phortynska@yahoo.com

* Correspondence: akocira@pwsz.chelm.pl; Tel.: +48-82-565-8895

Abstract: There has been a significant increase in the development of edible films and coatings in recent times, and this is expected to have a significant impact on the quality of fruit and vegetables in the coming years. Consumers expect fresh fruit and vegetables free from pesticide residues, with high quality, nutritional value and an extended shelf life. The application of coatings and edible films to fruits and vegetables represents an environmentally friendly approach to an innovative solution to this problem. Coatings and edible films can act as ecological and biodegradable packaging. The coating strategy involves a combination of natural biopolymers and appropriate preservation methods. The article presents the applicability, trends and perspectives of polysaccharide coatings and edible films and their impact on the quality of fruit and vegetables, providing an understanding of their main functions and benefits. Numerous studies show that natural polysaccharides are well suited for use as packaging material for fresh fruit and vegetables and can often be an important alternative to synthetic compounds. Natural polymer materials are a good barrier to oxygen and carbon dioxide; however, they are characterised by excessive solubility in the water environment, water vapour permeability and low extensibility. The properties of edible coatings can be modified by the addition of plasticisers, surfactants, cross-linkers, antimicrobial agents, functional additives, nanosilver particles or fruit and vegetable residues. The use of an electric field is also a promising technology here. The use of polysaccharides for the preparation of edible films and coatings is justified not only by the possibility of reducing the consumption of packaging made of synthetic polymer materials but also by the fact that the production of some natural polymers can be made using waste products generated during the processing of food raw materials.

Keywords: cellulose derivatives; chitosan and chitin; edible films and coatings; fruit and vegetables; gums; economic aspects and legislation; mechanical and physical properties; post-harvest quality; pectin; seaweed products; starch

\section{Introduction}

Fruit and vegetables are essential in the human diet for their nutritional value. They are a rich source of vitamins, essential minerals, antioxidants, bioflavonoids and dietary fibre [1]. Fruit and vegetables are living tissues and highly perishable products needing optimal post-harvest technologies in order to maintain their storage stability and extend 
their shelf life. The quality and stability of fruit and vegetables depends on the variety, pre-harvest practices, climatic conditions, ripeness at harvest, harvest methodology and post-harvest conditions, making the prediction of shelf life a difficult task compared to other foods. Their short storage times are evidenced by physiological, biochemical and microbiological changes, including respiration and transpiration, which lead to significant economic losses. An important condition for preserving the shelf life of fruits and vegetables is a proper method of storage and control of their quality parameters, such as colour, firmness, ethanol fermentation, atmosphere composition, water content and weight loss [2-4].

Fruit and vegetables in their natural state are covered with a layer of waterproof waxes produced by biosynthesis, with a thickness ranging from a few micrometres to several millimetres. The substances included in natural waxes are hydrocarbons $(1-2 \%$ to $50-60 \%$ by weight), esters (from $5 \%$ to $20 \%$ by weight), free alcohols (from $4 \%$ to $50 \%$ by weight), fatty acids (approx. $10 \%$ by weight) as well as aldehydes and ketones. Natural waxes slow down the life processes of plants after harvesting, contributing to their longer shelf life. They perform protective functions, inhibit losses, regulate gas exchange, protect against the penetration of undesirable substances from the external environment (pathogens, pollution) and protect the tissue against damage. The thin layers of natural waxes on fruit and vegetables are damaged during storage and distribution. The complete removal of waxes occurs during sorting, washing, cleaning, peeling and cutting, and this initiates undesirable biochemical processes. Then, fruits and vegetables show reduced durability and a tendency to change colour and taste, lose their shine or turn brown $[5,6]$.

The demand for fresh fruit and vegetables has forced the industry to develop new and better methods of maintaining quality and extending their shelf life. Extending the shelf life not only improves the quality, taste and texture of fruit and vegetables but also reduces waste and associated costs. One such solution is the use of natural and biodegradable food films and coatings, which can be a good alternative to synthetic fungicides. They can effectively delay the deterioration of fruit and vegetables, extend the shelf life and also protect them against the harmful effects of the environment. They are safe, functional and environmentally friendly [3,7]. As semi-permeable membranes, they allow the permeation of gases and electrolytes between the product and the environment. The addition of sweeteners, flavours and dyes to edible films and coatings may increase the sensory attractiveness of fruit and vegetables, and enriching them with antioxidant compounds improves their nutritional and health values [8].

Edible films and coatings come into direct contact with plant products; therefore, they must meet certain legal and functional requirements. Among other requirements, they should not be harmful to health; have good barrier properties to UV rays, moisture, oils and gases; dissolve well in water and fats; and have adequate resistance to microbiological, biochemical or physicochemical changes. These properties depend on the type of natural polymer, the method of modification in the production process (physical, chemical or enzymatic cross-linking) and the method and conditions of forming the film and coating $[9,10]$.

Natural and biodegradable edible films and coatings are a sustainable alternative to plastic packaging commonly used in the market. In view of the above, and due to the importance attached to improving the post-harvest quality of fruit and vegetables, the aim of this review is to analyse the latest trends and prospects for the use of edible polysaccharide films and coatings as an effective preservative to ensure the safety, quality and functionality of fresh fruit and vegetables.

\section{Definition and Methods of Applying Edible Films and Coatings}

Edible films and coatings are defined as any thin material used to wrap or coat a product to extend its shelf life, which can be consumed with the product. They can improve the quality of, e.g., fruits and vegetables by protecting them from physical, chemical and microbiological changes such as moisture loss, enzymatic browning reactions and fat 
oxidation [11]. The thin layer formed by the edible materials that cover the fruit and vegetables is called the edible coating, while the layer previously shaped and placed on the raw material is called the edible film. The edible coatings are in liquid form and are applied to the raw material by immersing it in the solution. Edible films are shaped like a solid sheet and then applied by wrapping around the product $[2,12,13]$.

For a long time, edible films and coatings have been used mainly as a one-component film or coating formulation. However, recently, a number of studies have been carried out on two-component and multi-component edible materials that provide better functional properties. In such a case, composite films or coatings are prepared by combining two or more binders to obtain structures with modified physical, mechanical and barrier properties that are superior to a single-component material. Therefore, various substances are used in film-forming preparations, such as plasticisers (glycerol, polyoxyethylene glycol, propylene glycol, sorbitol), cross-linkers, emulsifiers and enhancers (vegetable fatty acids) to improve or modify the basic functionality of the material [3,14-16]. However, introduced in excess, they may deteriorate mechanical properties and increase water vapour permeability (polypropylene glycol, sorbitol). Edible films and coatings have a number of advantages over synthetic coatings:

- They act as a gas and moisture barrier that creates a modified atmosphere in the fruit, which, in turn, extends the shelf life and preserves the quality of fresh fruit and vegetables.

- They act as a barrier against microorganisms and thus contribute to proper hygiene.

- Several active ingredients such as anti-browning agents, dyes, aromas, nutrients and spices can be incorporated into the polymer matrix and consumed with the fruit, thus increasing safety and even nutritional and sensory properties.

- They help to reduce synthetic packaging waste due to their biodegradable nature $[2,13,17-19]$.

When creating edible films and coatings, the aim is to obtain durable, thin and homogeneous materials [20]. They can be produced by wet or dry methods. One of the wet production methods is to obtain edible films by removing the solvent used to prepare the film-forming solution. In this process, as a result of the physico-chemical intermolecular interaction, a continuous structure is formed and stabilised. The macromolecules of the film-forming solution are dissolved in a solvent (water, ethyl alcohol, acetic acid) and can be combined with other additives. The resulting film-forming solution is poured in a thin layer, dried and then removed from the surface [21]. The structure of the film is influenced by the drying conditions (temperature, relative humidity), the thickness of the film-forming solution layer and its composition $[14,22,23]$. Coatings are formed on the surface of fruit or vegetables from a liquid solution by dipping in a film-forming mixture, as well as by spraying or lubricating the surface [24]. This casting method is the most popular technique on a laboratory scale, although there are also some industrial-scale applications. The properties of the coating solution (density, viscosity, surface tension, food immersion speed) are important in this method [25]. The multilayer technique is used here, in which fruits and vegetables are electrolytically coated in layer by layer [21]. The coating process is carried out at an appropriate temperature in order to ensure the fluidity of the ingredients, create a specific thickness and even create coverage of the surface of fruits and vegetables. Cohesion of particles in the coating structure and adhesion between the coating and the surface of the plant product takes place during the coating process. The intensity of the cohesive forces directly affects the barrier and mechanical properties of the covering layer, which depend on the methods of formation [26].

Edible films and coatings can also be prepared by extrusion [27]. Extrusion is often preferred to casting as the method of fabricating films because the throughput of the process is faster and less energy is required for the removal of water [28]. The successful application of extrusion depends upon the main variables that should be controlled during the extrusion process. These variables include food polymer selection, liquid feed rates, screw configuration, screw speed, zone temperatures, product inlet/outlet pressures (and 
their differentials) as well as die configuration [29]. Although extrusion is a promising approach for the elaboration of edible films, there are a limited number of studies related to the use of this technology on pectin edible film elaboration. Probably, this is due to the behaviour and chemical interaction of food ingredients during extrusion, which is difficult to understand, along with many processing variables that need to be controlled $[30,31]$. Thus, Fishman et al. [28] used extrusion to prepare edible films from pectin/starch blends plasticised with glycerol. They used a twin-screw extruder with nine heating zones. As a result of the research, the authors found that the extruded edible films have a microstructure and thermodynamic mechanical properties comparable to those obtained by casting from a solution containing the same materials. Pectin films with various combinations of orange albedo and starch were produced under similar conditions [28]. In addition, Liu et al. [29] investigated optimal extrusion parameter conditions for the production of edible packaging films derived from food polymers. The authors indicated that the optimal conditions for the pectin films are temperatures in extruder zones 3 and zone 4 of $125^{\circ} \mathrm{C}$ and $110{ }^{\circ} \mathrm{C}$, respectively and a screw speed of $225 \mathrm{rpm}$. These conditions were determined on the basis of the evaluation of the physical and mechanical properties of the films, such as tensile strength, elongation, puncture resistance, colour, Young's modulus, tear resistance, haze and thickness [29,31].

Films and coatings made from a single polymeric component are often brittle and breakable. To counteract this, a plasticiser, allowing the formation of an elastic structure, is introduced into the film-forming solution. The plasticiser enters the molecular chains of polymers and their physicochemical connections, thus increasing the coherence. The most commonly used plasticisers are polyols (glycerol, sorbitol, polyethylene glycol), sugars (glucose, honey) and lipids (monoglycerides, phospholipids). The appropriate selection of a plasticiser for films and coatings is important as it can significantly change the physicochemical properties of the coatings [21]. The methods and possibilities of coating fruits and vegetables depend on the type of product and its properties, storage and distribution conditions [32,33].

Scientists have investigated various polymers of biological origin to obtain a continuous structure of membranes or coatings. Polysaccharide hydrocolloids are the most common group of biopolymers used in the production of edible films and coatings. They can be obtained from sources such as plants, crustaceans and microorganisms. Cellulose derivatives, starches, alginates, pectins, chitosans, pullulan and carrageenans are the most popular polysaccharides used in the production of edible films and coatings [2]. However, these materials are hydrophilic in nature. Therefore, different types of oils and fats are incorporated into the hydrocolloid matrix to enhance their water vapour barrier properties. The most popular are waxes, triglycerides, acetylated monoglycerides, free fatty acids and vegetable oils [34].

\section{Characteristics of Selected Polysaccharides}

3.1. Seaweed Products-Alginate, Carrageenan and Agar

Alginate, carrageenan and agar are products obtained from species of marine algae belonging mainly to Phaeophyceae (brown algae) and Rhodophyceae (red algae) (Table 1). 
Table 1. Occurrence of polysaccharides in marine algae [35].

\begin{tabular}{ccc}
\hline \multirow{2}{*}{ Polysaccharide } & \multicolumn{2}{c}{ Phylum (Division)/Species of Seaweeds } \\
\cline { 2 - 3 } & Phaeophyceae & Rhodophyceae \\
\hline & Macrocystis & \\
& Laminaria & \\
Ascophyllum & Ecklonia & \\
Alginates & Eisenia & \\
& Nereocystis & \\
& Sargassum & Chondrus \\
& & Gigartina \\
& & Eucheuma \\
& & Hypnea \\
& & Iridaea \\
& & Kappaphycus \\
& & Gymogongrus \\
& & Ahnfeltia \\
& & Furcellaria \\
& & Gelidium \\
& & Gracilaria \\
& & Pterocladia
\end{tabular}

Alginate, the sodium salt of alginic acid, is a brown seaweed product hat exhibits film-forming properties [14,36]. The colloidal properties of these biopolymers used as film or coating constituents are related to their chemical structure [37,38]. Alginate coating materials are made by the use of divalent cations such as $\mathrm{Ca}, \mathrm{Mg}, \mathrm{Mn}, \mathrm{Al}$ and $\mathrm{Fe}$, and it is used as a gelling agent $[39,40]$. Alginate consists of D-mannuronic acid (M) and Lguluronic acid $(G)$ in various proportions, arrangements and molecular weights $[35,37,41]$. The physical properties of alginate gels largely depend, among others, on the ratio of guluronic acid to mannuronic acid residues, the successive order of these residues, the length of guluronic acid blocks and the total molecular weight of the polymer [41-43]. If the $M / G$ ratio $<1$, the gel indicates a large amount of guluronic acid, which is capable of forming strong bonds. If the $M / G$ ratio > 1 , the gel contains less guluronic acid, which may result in softer and more flexible structures [44]. On the other hand, alginic acid obtained from different species of brown algae may also be different, as it may contain three types of polymer segments and consist of (a) mainly D-mannuronic acid (M) units, (b) mainly L-guluronic acid units $(\mathrm{G})$ or (c) alternating D-mannuronic acid and L-guluronic acid residues [35] (Table 2). 
Table 2. Alginate composition of selected brown algae species.

\begin{tabular}{|c|c|c|c|c|}
\hline Species & $\begin{array}{c}\text { Mannuronic Acid (M), } \\
\text { wt } \%\end{array}$ & $\begin{array}{l}\text { Guluronic Acid (G), } \\
\text { wt } \%\end{array}$ & M:G Ratio & References \\
\hline Laminaria digitata & $53-59$ & $41-47$ & $2.20-3.60$ & {$[35,45]$} \\
\hline Laminaria hyperborea & $30-38$ & $62-70$ & 0.45 & {$[35,46,47]$} \\
\hline Laminaria japonica & 69 & 31 & 2.26 & [48] \\
\hline Ascophyllum nodosum & $60-65$ & $35-40$ & $1.40-2.25$ & {$[35,45,46]$} \\
\hline Ecklonia cava & $62-67$ & $33-38$ & $1.60-2.00$ & {$[35,49]$} \\
\hline Eisenia bicyclis & 62 & 38 & 1.60 & [35] \\
\hline Macrocystis pyrifera & $50-61$ & $39-50$ & 1.56 & {$[36,45,48]$} \\
\hline Durvillae antarctica & 56 & 44 & 1.27 & [50] \\
\hline Sargassum ringgoldianum & $64-70$ & $30-36$ & $1.80-2.30$ & [51] \\
\hline Sargassum turbinaroides & 49 & 52 & 0.94 & [52] \\
\hline Sargassum fluitans & $34-54$ & $46-66$ & $0.52-1.18$ & [53] \\
\hline Sargassum muticum & 24 & 76 & 0.31 & [54] \\
\hline Sargassum polycystum & 18 & 82 & 0.21 & [54] \\
\hline Nereocystis luetkeana & 63 & 37 & 1.70 & [55] \\
\hline Pelvetia canaliculata & $56-60$ & $40-44$ & $1.30-1.50$ & [56] \\
\hline Undaria pinnatifida & 60 & 40 & 1.50 & [48] \\
\hline
\end{tabular}

The ability of alginate to irreversibly and immediately react with divalent and trivalent metal cations $\left(\mathrm{Ca}^{2+}\right.$ and $\left.\mathrm{Ca}^{3+}\right)$ and to form water-insoluble polymers is used to form coatings of edible vegetables and fruit [57]. Alginates have good film-forming properties, giving a uniform, transparent, glossy look to films [2,39,58]. Films (membranes) made of alginates are impermeable to fats and oils, and like other hydrophilic polysaccharides, they are distinguished by high water vapour permeability $[37,39,57]$. Alginate has a unique colloidal property, which contains a stabilising, thickening, suspending film or coating, producing gel-forming and stabilising emulsion [40,57]. Alginate has some desirable properties, including reduction in shrinkage, moisture retention, colour and odour of food [39]. The alginate gel coating can protect vegetables and fruit from loss of turgor, as moisture is first lost from the edible coating before the protected parts of the edible plants are significantly dehydrated [58,59]. Alginate coatings provide a good barrier to oxygen, which contributes to the delay of lipid oxidation in vegetables and fruits and reduces their weight loss and the abundance of microflora on the surface $[58,60,61]$. They also contribute to delaying the ageing processes that take place in fruits and vegetables during their storage [62].

To extract the alginate, the seaweed is broken into pieces and mixed with a hot base solution (e.g., sodium carbonate). After about $2 \mathrm{~h}$, the alginate dissolves as sodium alginate, forming a thick slurry that also has undissolved parts of the seaweed (glycellulose). The resulting solution is diluted with water and pressed through a filter cloth in a filter press along with an auxiliary filter, e.g., diatomaceous earth. The last step is the alginate precipitation from the filtered solution as alginic acid or calcium alginate [63,64]. Pretreatment of the seaweed with acid (prior to alkaline extraction) leads to a more efficient extraction, less coloured product and reduced viscosity loss during extraction due to the lower amount of phenolic compounds [65]. Due to the linear structure, alginate can form strong films and appropriate fibrous structures in the solid state; therefore, it is considered a good filmogenic material [44].

Carrageenans are natural hydrophilic polymers with a linear chain of partially sulphated galactans that have high membrane formation potential [34,66]. However, the production of edible films using carrageenans is not as popular as they are most commonly used as coatings [67]. They are extracted from the cell walls of red algae, most often from the species Chondrus crispus, Kappaphycus alvarezii and Eucheuma denticulatum [34,63] (Table 1). There are three types of carrageenan: kappa carrageenan ( $\kappa$-carrageenan), iota carrageenan ( $\mathrm{l}$-carrageenan) and lambda carrageenan ( $\lambda$-carrageenan) [68]. The solubility of carrageenans in water depends on the content of ester sulphate and associated cations. 
Higher levels of ester sulphate mean a lower dissolution temperature. The presence of cations such as $\mathrm{Na}, \mathrm{K}, \mathrm{Ca}$ and $\mathrm{Mg}$ promotes cation-dependent aggregation between carrageenan helices. Depending on the concentration of the solution, the melting point of carrageenans is from 50 to $70^{\circ} \mathrm{C}$ and the gelation temperature is from 30 to $50{ }^{\circ} \mathrm{C}[63,69]$. Iota carrageenan forms elastic and clear gels with no syneresis in the presence of calcium salts [63]. Edible films based on iota carrageenan have good mechanical properties as they are emulsion stabilisers and can reduce oxygen transfer and limit surface dehydration and deterioration of fruit flavour [70]. Lambda carrageenan, on the other hand, does not form a gel but only forms highly viscous solutions; therefore, it cannot be used as an edible film [71]. Kappa carrageenan is one of the most common forms of carrageenan that can be used in food, and the gel made from it can be frozen and thawed. Kappa carrageenan has a double-helix conformation, and the linear helical parts can associate to form a three-dimensional gel in the presence of appropriate cations [72]. Kappa carrageenan creates strong and stiff gels with potassium salts and brittle gels with calcium salts. Kappa carrageenan gels are opaque but become clear when sugar is added [63]. These coatings, like others, obtained from seaweeds, effectively protect vegetables and fruit against loss of moisture and turgor, oxidation of compounds and ageing processes and, in combination with ascorbic acid, reduce the number of microorganisms [36].

Carrageenan was previously obtained by the method of extracting into an aqueous solution. After the filtrate containing the seaweed residues has been removed, the carrageenan should be recovered from the solution. However, this method is expensive, and nowadays carrageenan is obtained by a method in which the seaweed is washed to remove solid impurities and then treated with alkali to extract the carrageenan. After extraction, the diluted extracts (1-2\% carrageenan) are filtered, concentrated and then precipitated with isopropanol until a fibrous coagulum is obtained. The coagulum is pressed to remove the solvent and washed. It is then dried and milled to the appropriate particle size [63].

Agar is a mixture of agarose (gelling fraction) and agaropectin (non-gelling fraction) that is obtained from red seaweed [73]. Agarose creates a supporting structure in the cell walls of red algae and is responsible for the gelling properties of agar, making it suitable for the formation of edible coatings of vegetables and fruit [74]. Agar is mainly made of galactose units with a regular alternation of L and D isomeric forms. Agar gel compared with kappa carrageenan has increased strength and a higher melting point, which is related to the lower content of anionic sulphates. Agar gel melts when heated to $85^{\circ} \mathrm{C}$ and resets when cooled to $31-40^{\circ} \mathrm{C}$. However, the viscosity of agar in solution at $60{ }^{\circ} \mathrm{C}$ is lower than that of carrageenan. Agar has the ability to form strong, thermoreversible gels and is known for its hydrophilicity. Agar films and coatings are transparent, strong and stiff and insoluble in water under ambient conditions [69].

Agar is most often obtained by alkaline treatment followed by hot-water extraction. The alkaline treatment causes a chemical change in the agar (formation of 3,6-anhydrogalactopyranose), resulting in increased gel strength. Extraction with hot water (temperature around $100^{\circ} \mathrm{C}$ ) takes about $2-4 \mathrm{~h}$, sometimes under pressure. The agar is dissolved in water, and the seaweed residues are removed by filtration. The agar is then recovered by alcohol precipitation [75].

\subsection{Gums}

Gum arabic (synonymous with acacia gum) is a polysaccharide obtained from the gummy exudate of the stems and branches of the species of the genus Acacia, most often of the species Acacia senegal (L.) Willd. var. senegal. Gum arabic can also be obtained from the following species: Acacia senegal var. karensis, Acacia seyal var. seyaland, Acacia seyal var. fistula, Acacia polyacantha, Acacia gerrardii, Acacia laeta, Acacia nilotica and Acacia fischeri [76]. Gum arabic is a complex, branched, anionic, hydrophilic heteropolysaccharide with a backbone of 1,3-linked $\beta$-galactopyranose units and side chains of 1,6-linked galactopyranose or arabinose units terminating in rhamnose or glucuronic acid or 4-O-methlglucuronic acid residues, which contains about $2 \%$ protein substance and is classified as an arabinogalactan- 
protein complex [76,77]. Depending on the source of the nodules, it may have a variable composition and different physical and chemical properties. Among the hydrocolloids, gum arabic is the least viscous and more soluble and has good emulsifying and filmforming properties [76-80]. Tara gum is obtained by ground endosperm of the seeds of the Cesalpinia spinosa tree. It consists of linear chains of $(1 \rightarrow 4)$ - $\beta$-D-mannopyranosyl residues having single side chain units of $(1 \rightarrow 6)-\alpha$-D-galactopyranosyl, in a ratio of 3:1. Galactomannans (including tara gum) have high viscosity, water-binding capacity and the ability to synergistically interact with other polymers. Tara gum, based on steric hindrance, possesses less galactose substitution compared with guar gum (other galactomannan), which is why it can make stronger films [81,82]. However, the edible film produced from it has relatively poor mechanical and water vapour barrier properties [83].

Guar gum is a hydrophilic carbohydrate biopolymer obtained from the seeds of Cyamopsis tetragonoloba. It consists of a linear long-chain molecule of $\beta(1 \rightarrow 4)$-linked Dmannose residues with single linked $\alpha(1 \rightarrow 6)$-D-galactose, in which the ratio of mannose to galactose units varies from 1.5:1 to 1.8:1. Guar gum can form a homogeneous edible film that is almost completely soluble in water due to the large number of hydroxyl groups $[84,85]$.

In turn, xanthan gum is an extracellular heteropolysaccharide produced by submerged aerobic fermentation of a pure Xanthomonas campestris culture [86,87]. Due to the ability to create highly viscous solutions at low concentrations and its biodegradability, it is used as an additive to starch-based films, improving some of its mechanical properties [88].

Basil seed gum (Ocimum basilicum L.) is an acidic (anionic) polysaccharide from which edible film can be made [89]. Basil seed gum consists of two main fractions of glucomannan $(43 \%)$, with a glucose-to-mannose ratio of 10:2, and (1 $\rightarrow 4)$-linked xylan $(24.29 \%)$ and a minor fraction of glucan $(2.31 \%)$. This gum can be used to produce films with good appearance and satisfactory mechanical properties. However, the improvement of the mechanical properties of this film, including extensibility and increased water solubility, can be obtained by adding glycerol [90].

Edible films and coatings made of polysaccharide gums form a semi-permeable barrier. This helps to maintain the nutritional value of fruit and vegetables, although weight loss may occur and the rate of respiration at the surface may be reduced. Edible coatings of this type not only improve the shelf life of fruits and vegetables and prevent their quality deterioration during storage but also protect them against pathogens [62,91].

\subsection{Pectin}

Pectin is a component of plant fibre and can be extracted from the plant cell walls. It is a complex anionic polysaccharide composed of $\beta$-1,4-linked $\alpha$-D-galacturonic acid residues, where the uronic acid carboxyls are either fully (high methoxy pectin) or partially (low methoxy pectin) methyl-esterified [82,92]. Pectin-based films and coatings have excellent mechanical properties. Raw materials rich in pectin can be used as a potential natural plasticiser, improving the extensibility of edible films [93]. However, pectin-based films are poor moisture barriers and are therefore recommended for food with low moisture content [62]. Edible films produced from high methoxy pectin have more favourable features. In the process of plasticising pectin and starch with a high amylase content, strong and flexible edible and biodegradable films are obtained, which, after plasticising with glycerol, have good mechanical and oxygen barrier properties [92,94].

\subsection{Cellulose Derivatives}

The most common natural polymer in nature is cellulose. Cellulose consists of Dglucose units linked through $\beta-1,4$-glycosidic bonds. It is an almost linear polymer in which a highly crystalline structure is obtained due to the tight packing of anhydroglucose polymer chains. Cellulose is insoluble in water due to the large number of intramolecular hydrogen bonds. The water solubility of cellulose can be increased by treating with alkali so that its structure swells. For this, a reaction with methyl chloride, chloroacetic acid or propy- 
lene oxide is carried out to obtain methyl cellulose (MC), carboxymethyl cellulose (CMC), hydroxylpropyl cellulose (HPC) or hydroxypropyl methyl cellulose (HPMC) [92,95,96]. Methyl cellulose, hydroxypropyl methyl cellulose and hydroxylpropyl cellulose films have good film-forming properties and are also biodegradable, tasteless, odourless, flexible, of moderate strength, transparent, resistant to fats and oils as well as water-soluble and moderately permeable to moisture and gases (oxygen and carbon dioxide) $[62,92,96]$. Cellulose-based films and coatings, which have a large surface area and biopolymer structures, are able to retain most of water in the product and therefore exhibit anti-rancidity effect [97]. The water vapour permeability of these films is highly influenced by the hydrophobic:hydrophilic ratio of the film components [96]. Krochta et al. [98] showed that the characteristics of cellulose, including its gas and moisture barrier, were dependent on its molecular weight and that the higher the molecular weight, the better the properties. Edible films obtained with carboxymethyl cellulose are an effective barrier to the penetration of oxygen and carbon dioxide but have a poor water barrier [99]. Carboxymethyl cellulose-based edible films can be used as a suitable carrier for some probiotic strains and have significantly improved vapour permeability [100]. It has also been found that mixing carboxymethyl cellulose with other polymers, e.g., starch and chitosan, increases the inherent CMC shortcomings [62]. Methylcellulose is less hydrophilic and provides a better moisture barrier $[92,96,101]$. Moreover, it is widely used as a carrier of antibacterial agents in the production of edible films $[98,100]$. In turn, films based on hydroxypropyl methyl cellulose create a good gas barrier [102].

\subsection{Starch}

Starch accumulates primarily in the tubers, seeds and roots of plants. For industry, it is most often obtained from maize, wheat, edible cassava, potato, amaranth and quinoa [30]. Glucose polymerisation in the starch molecule results in the formation of two polysaccharide fractions, linear amylose and branched amylopectin, which together constitute about $98-99 \%$ of the dry weight of starch and are packed in concentric rings that form semicrystalline and amorphous layers $[103,104]$. Both fractions consist of chains composed of $\alpha$-D-glucopyranose residues linked by $\alpha$-1,4-glycosidic bonds, and the chains, in turn, are linked by $\alpha-1,6$-glycosidic bonds, thus creating branches in polymers. Amylose $(20-30 \%)$ is a polymer with a linear structure, which greatly influences the amorphous form of starch granules $[30,105]$. Due to its linear structure, it tends to orient itself in parallel. This causes the formation of hydrogen bonds between hydroxyl groups, reducing the affinity of the polymer to water and, as a result, enabling the formation of membranes and gels [106]. Amylopectin $(70-80 \%)$ has a highly branched structure, and its structure influences the peripheral crystal organisation of starch grains. Amylose and amylopectin are assembled naturally in granular forms, about $1-100 \mu \mathrm{m}$ in size $[30,107]$. Moreover, the distribution of the unit chain length in the internal structure of amylose and amylopectin affects the thermal properties and the starch retrogradation profile [108]. The content of these components in starch determines the properties of the film, as edible films with higher amylose content have better film-forming properties, i.e., better mechanical strength, elongation and gas barrier properties [29]. To produce coatings with a higher amylose content, this polymer can be extracted from starch by selective leaching in hot water $\left(50-70{ }^{\circ} \mathrm{C}\right)$ [109]. After cooling, starch forms a gel. During gelation, amylose and amylopectin undergo intra- and intermolecular cross-linking. As a result, macromolecular networks are formed $[29,110]$.

Depending on the source of starch, the content of amylose and amylopectin varies significantly, as does the size of the granules (granules) and their shape (Table 3). These features affect the functionality, barrier, mechanical and sorption properties of the starch. On the other hand, the sorption properties of starch influence the composition of the coatings, the process of their formation, methods of applying to the product and application $[111,112]$. 
Table 3. Amylose and amylopectin content and granule size in various plant products.

\begin{tabular}{ccccc}
\hline Starch Source & Amylose (\%) & Amylopectin (\%) & Average Granule Size ( $\mu$ m) & References \\
\hline Potato & $21-30$ & $70-79$ & $36-100$ & {$[113-115]$} \\
Tapioca & 17 & 83 & 14 & {$[113]$} \\
Corn & $19-26$ & $74-81$ & 13.3 & {$[113,115]$} \\
Corn (waxy) & 1 & 99 & - & {$[113,115]$} \\
Corn (high amylose) & $50-85$ & $15-50$ & $7-20$ & {$[113]$} \\
Wheat & $19-25$ & $75-81$ & $6-8$ & {$[113,115]$} \\
Rice & 17 & 83 & $2-40$ & {$[114]$} \\
Pea (smooth) & $33-50$ & $50-67$ & $17-30$ & {$[113]$} \\
Pea (wrinkled) & $61-88$ & $12-39$ & $1-3$ & {$[113]$} \\
Amaranth & $5-22$ & $78-95$ & & {$[114]$} \\
\hline
\end{tabular}

The use of starch as a component of edible coatings is possible due to its good barrier to gases (carbon dioxide, oxygen), adequate durability and cohesive strength. Moreover, starch films are odourless, tasteless, colourless and non-toxic $[9,116]$. However, a major limitation in the use of starch is the high water vapour permeability, which additionally adversely affects the mechanical properties of the coating $[30,117]$. Therefore, components with hydrophobic properties are often added in the film production phase, e.g., oleic acid and polyethylene glycol [118]. Starch does not dissolve in water, but with increasing water temperature, it strongly swells and dissolves in an alkaline environment. Starch films are produced by pouring starch dispersion on a smooth surface and then drying them [119]. When forming a starch film, first the starch granules are heated in excess water to prepare a viscous solution. However, aqueous solutions are usually unstable and tend to gel immediately after cooling due to the association of the polymer chains [120]. Therefore, at high temperatures and in excess of water, the starch undergoes a transformation known as gelatinisation, during which the starch granules change from the semi-crystalline phase to the amorphous state [121]. The loss of crystallinity occurs in two stages, the first of which involves swelling of the starch molecule at $60-70{ }^{\circ} \mathrm{C}$ [122] and the second, excessive swelling and solubilisation of the granule at temperatures above $90{ }^{\circ} \mathrm{C}$, leading to a complete loss of structural integrity [123]. This process depends on the ratio of amylose to amylopectin, water content and temperature of the dispersion, which, in turn, influences the recrystallisation of starch during retrogradation. Once the chain interactions are complete, the weight of the gel is reduced by further evaporating the water until most of the free water is removed. During the retrogradation, the dissociated amylose and amylopectin chains in a gelatinised starch dispersion reunite to form more ordered structures. This process affects the permeability, solubility and mechanical properties of starch films $[113,120]$.

\subsection{Chitosan and Chitin}

Chitin is a biopolymer that occurs naturally in the exoskeleton of crustaceans (shrimps, oysters, krill, crabs, squid, lobsters), the cell walls of filamentous fungi (Mucoraceae) and other biological materials such as arachnids and insects (bumblebees, crickets, bees, silkworm larval skin) [124-126]. Chitin consists mainly of poly( $\beta-(1-4)-2$-acetamido-D-glucose), and unlike structurally identical cellulose, the acetamide group here replaces the secondary hydroxyl on the second carbon atom of the repeating hexose unit (secondary hydroxyl on the second carbon atom of the hexose repeat unit) $[127,128]$. Chitosan is obtained by $\mathrm{N}$-deacetylation of chitin in an alkaline environment [129]. It is a copolymer consisting of $\beta$-(1-4)-2-acetamido-D-glucose and $\beta$-(1-4)-2-amino-D-glucose units, with the latter usually exceeding $60 \%$ [127]. Chitosan is a non-toxic, non-allergenic, biodegradable, biocompatible and film-forming material with beneficial biological effects (antifungal, antibacterial, antitumour) [130-132]. Chitosan films are characterised by selective gas permeability $\left(\mathrm{CO}_{2}\right.$ and $\mathrm{O}_{2}$ ) and good mechanical properties and are biodegradable, so they are not harmful to the environment [9]. 
Edible chitosan coating applied to the surface of fruit and vegetables reduces their respiration rate by regulating gas permeability [133]. However, due to high water vapour permeability, their use as edible films is limited, especially in humid environments [127,134]. Water vapour permeability is a parameter that ensures the organoleptic properties of stored vegetables and fruit, as well as the ability to fight against dehydration or rehydration of the film [135]. Another factor limiting the direct use of chitosan as an edible coating is its low water solubility, which results from its rigid crystal structure [132].

The antifungal and antimicrobial activity of chitosan results from its polycationic nature [136]. Its antibacterial activity is mediated by electrostatic forces between the protonated amino group $\left(\mathrm{NH}_{2}\right)$ in chitosan and negative residues on the cell surface [137], while the greater number of protonated amino groups $\left(\mathrm{NH}_{2}\right)$ present in chitosan is associated with an increase in deacetylation degrees (DD) [138]. According to Liu et al. [138] the bactericidal effect of chitosan is influenced by the electrostatic interaction between the $\mathrm{NH}^{3+}$ groups of chitosan and the phosphoryl groups of the phospholipid component of the cell membrane. Chitosan particles change the permeability of bacterial cell membranes, hindering the gas exchange of their cells with the environment, as well as lead to cell dysfunction through cell penetration or rupture of the cell membrane [139-142]. Chitosan forms edible coatings and films that protect vegetables and fruit against deterioration and microbial contamination, helping to maintain their quality and contributing to the extension of their shelf life [62,143].

About $30 \%$ of chitin is obtained from shrimp shells. In this process, proteins are removed by reaction with a weak $\mathrm{NaOH}$ solution (1-10\%) at elevated temperatures $\left(85-110{ }^{\circ} \mathrm{C}\right)$. After shredding the shells, a weak $\mathrm{HCl}$ solution $(1-10 \%)$ is used at room temperature to remove $\mathrm{CaCO}_{3}$. The physicochemical properties of chitin are determined by the parameters of the extraction performed, e.g., temperature, concentration of the reagents used, their duration of action and the size of the shells. The basic parameters that characterise chitin are the degree of polymerisation, the degree of deacetylation and purity. When chitin becomes soluble in weak acids, it can be regarded as chitosan, which is formed during the treatment of chitin with a strong solution of $\mathrm{NaOH}$ (over $40 \%$ ) at a temperature of $90-120{ }^{\circ} \mathrm{C}$. In the deacetylation reaction, the acetyl groups $\left(\mathrm{CH}_{3} \mathrm{CO}^{-}\right)$are removed from the amino groups and soluble chitosan is formed. To obtain a soluble product, at least $65 \%$ of the acetyl groups should be removed from the chitin molecule. The degree of deacetylation depends on the duration of the reaction, temperature and concentration of $\mathrm{NaOH}$ solution [128]. The physicochemical characteristics of chitosan, e.g., molecular weight, polydispersity and purity, depend on the method used, the apparatus used and the source of the armour. Moreover, the total length of the polymer chain has a direct impact on its weight, and as the chain shortens, the water solubility of chitosan increases. The parameter determining the properties of chitosan is also the degree of chitin deacetylation, which, depending on the technological process, may be $70-100 \%$. This parameter is important as it indicates the positive charge of the molecules when dissolved in a weak acid. An important parameter from the point of view of applications is also purity, which is determined by the content of such contaminants as proteins, dusts, insoluble compounds, bacteria and endotoxins. Contaminants block the active amino groups of chitosan, which reduces the effectiveness of its action. Therefore, it is important to precisely control the methods of its production.

The enzymatic process, as well as the chemical one, leads to the conversion of $\mathrm{N}$ acetylglucosamine units into glucosamine units but is carried out under much milder conditions and is not associated with the simultaneous hydrolysis of the polymer chain. Chitin deacetylases take part in the enzymatic deacetylation process [144]. The enzymatic reaction can produce chitosan with a higher molecular weight and the desired degree of deacetylation compared to a polymer obtained by chemical processes [145]. Other enzymes involved in the conversion of chitin and chitosan include chitinases and chitosanases, which catalyse the hydrolysis of glycosidic bonds, but differ in their substrate specificity, hydrolysing chitin and chitosan bonds, respectively [146]. 


\section{Properties of Edible Films and Coatings}

The characteristics of biopolymer-based packaging materials depend on many different factors. The most important are the primary source of the biopolymer, the structural organisation of the polymer chain, the processing technology (preparation method and drying conditions) and the degree of cross-linking or crystallinity. Therefore, when using edible films and coatings for fruit and vegetables, it is necessary to take into account both the physical properties of biopolymer materials and their functional properties [14,147]. The physical properties of the new biopolymer films and coatings depend on the properties of the main components. Considering multi-component formulations, the chemical composition and miscibility of all components are crucial and affect most of the physical properties of biopolymer materials. The most common measured physical properties are mechanical resistance (tensile strength (TS), Young's modulus and elongation at break $€$ ) and water vapour permeability. The results of the physical and mechanical properties of the selected biopolymers are presented in Table 4.

The thickness and uniformity of edible films and coatings are among the parameters that affect the biological properties and shelf life of the coated raw materials. They depend on the properties of the solution itself (its density, viscosity, surface tension) and the method of producing films and coatings. The selection of the thickness of the cover layer is difficult as it depends on the polarity of the liquid (coating) layer and the surface of the raw material. Methods for measuring the thickness of the layer of edible films and coatings are divided into contact and non-contact. Contact methods are the simplest and consist in removing the coating layer from the product and measuring its thickness using a micrometer [148]. In the group of non-contact methods, the optical microscope, scanning electron microscope, confocal Raman microscope and surface-enhanced Raman spectroscopy are used to measure the thickness of the film layer [23].

Good mechanical properties are among the basic requirements for edible films, since poor flexibility or strength may lead to premature failure or cracking during production, handling, storage or use [149]. These measurements are important once the mechanical properties of films or coatings depend on the filmogenic nature of the material used, which is directly related to its structural cohesion [150]. Multiple factors, such as film composition, temperature, relative humidity and storage time, affect tensile properties. Generally, the addition of plasticisers leads to a decrease in the TS and an increase in E [151]. Polysaccharide films generally have a mechanical strength in the range of 15-70 MPa. The exception is amylopectin films, which have a lower mechanical strength-below $6 \mathrm{MPa}$ [152]. The mechanical properties of polysaccharide chitosan films depend on the $\mathrm{pH}$ of the environment (in an acidic environment films swell and may dissolve; in an environment with $\mathrm{pH}$, their solubility decreases) and the degree of polymer deacetylation. The mechanical properties of the film are determined by both the molecular weight of the chitosan and the type of acid in which it was dissolved to obtain the film. Chitosan films can be transparent, colourless or slightly yellowish [153]. The films obtained from starch (tapioca, Manihot esculenta Crantz) and xanthan gum or gellan (Xanthomonas campestris) are characterised by the highest extensibility $[86,154]$. Likewise, Young's modulus ranges from $0.014 \mathrm{MPa}$ for gum and protein isolate (Cajanus cajan (L.) Millsp. seed) to $2586 \mathrm{MPa}$ for starch and flour (pinhão, Araucaria angustifolia Kuntze) (Table 4).

The effectiveness of edible films and coatings in protecting fruit and vegetables from deterioration depends on their barrier properties against oxygen, carbon dioxide, nitrogen and water vapour. Relative humidity and temperature are the most important parameters when analysing the water vapour permeability (WVP) of polysaccharide coatings. It was shown that high temperature promoted gas transport through edible coatings in an exponential way [155]. Moreover, as the relative humidity increases, more water molecules interact with the material and the film becomes more plasticised [156]. Under these conditions, greater mobility and extensive mass transfer through the film are observed. Therefore, the antioxidant properties of edible coatings should be tested under controlled relative humidity conditions [60]. Biopolymer films show higher water vapour permeability 
values than synthetic films, which is attributed to the origin and parameters of the process. Most polysaccharide films are characterised as hydrophilic materials, and improving the water resistance of these materials has been of great interest to scientists in recent decades. Moreover, water resistance depends on the thickness of the film, which also affects other physical properties of the film [14]. Chitosan films and coatings are fully or partially water soluble and have the ability to form films without the need for other additives.

The measurement of the permeability of edible films to oxygen and carbon dioxide provides important information for the development of edible films. Oxygen is the factor that might cause oxidation, inducing several unwanted changes such as odour, colour and flavour, as well as nutrient deterioration. Both $\mathrm{O}_{2}$ and $\mathrm{CO}_{2}$ permeabilities are important when respiratory reactions can affect the quality of fruit and vegetables. Gas permeabilities of edible films and coatings depend on several factors such as the integrity of the film, the ratio between crystalline and amorphous zones, the hydrophilic-hydrophobic ratio and the polymeric chain mobility; the interaction between the film-forming polymers and the presence of a plasticiser or other additives are also important factors in film permeability [157]. Polysaccharides are usually mostly polar in nature. The resulting films are expected to be good barriers to nonpolar gasses, including oxygen [158]. The $\mathrm{PO}_{2}$ and $\mathrm{PCO}_{2}$ values of edible films are presented in Table 4. The tomato fruits coated with $10-15 \%$ gum arabic film yielded less weight loss during storage period than the control sample [80]. This suggests that gum arabic film exhibited effective semi-permeable barrier against $\mathrm{O}_{2}$, $\mathrm{CO}_{2}$, moisture and solute movement, which probably decreased respiration, water loss and oxidation reaction rates. The studies of Ruelas-Chacon et al. [159] showed that guar-coated tomatoes stored for 20 days had the lowest $\mathrm{CO}_{2}$ production $\left(2.8 \mathrm{~mL} \mathrm{~kg}^{-1} \mathrm{~h}^{-1}\right)$ compared with the control tomatoes $\left(10.7 \mathrm{~mL} \mathrm{~kg}^{-1} \mathrm{~h}^{-1}\right)$, indicating that coating might have modified the internal atmosphere and significantly delayed the respiration rate of tomatoes. The respiration rate in fresh fruit and vegetables is considered a good index for determination of storage life. The effect of polysaccharide-based coatings on respiration of horticultural products is related to their ability to create a barrier to oxygen diffusion through the coating. In tomatoes, coatings based on gum arabic [160,161], alginate [162] and hydroxyl propyl methyl cellulose (HPMC) also reduced the fruit respiration rate during storage [163]. Regardless of the modification, edible coatings provide a good oxygen barrier, increasing the oxidation stability and slowing down the respiration of fruits and vegetables [91].

In addition, these films and coatings are heat resistant and have good oxygen and carbon dioxide permeability, but less than synthetic polyethylene films. They also show good mechanical properties and are biodegradable and thus are not harmful to the environment. However, the disadvantage of these films and coatings is their poor resistance to moisture [9]. 
Table 4. Physical and mechanical properties of edible films and coatings.

\begin{tabular}{|c|c|c|c|c|c|c|c|}
\hline \multirow{2}{*}{ Polysaccharide/Components } & \multirow{2}{*}{$\begin{array}{l}\text { Water Vapour Permeability } \\
\text { (WVP) } \\
\left(10^{-11} \mathrm{~g} \mathrm{~m}^{-1} \mathrm{~Pa}^{-1} \mathrm{~s}^{-1}\right), \\
\text { at } 25^{\circ} \mathrm{C}\end{array}$} & \multirow{2}{*}{$\begin{array}{c}\text { Tensile Strength } \\
\text { (MPa) }\end{array}$} & \multirow{2}{*}{$\begin{array}{l}\text { Young's Modulus } \\
\text { (MPa) }\end{array}$} & \multirow{2}{*}{$\begin{array}{c}\text { Elongation at Break } \\
(\%)\end{array}$} & \multicolumn{2}{|c|}{$\begin{array}{c}\mathrm{O}_{2} / \mathrm{CO}_{2} \text { Permeability } \\
\left(\mathrm{mL} \mu \mathrm{m} /\left(\mathrm{m}^{2} \mathrm{~d} \mathrm{~Pa}\right)\right)\end{array}$} & \multirow{2}{*}{ References } \\
\hline & & & & & $\mathrm{PO}_{2}$ & $\mathrm{PCO}_{2}$ & \\
\hline $\begin{array}{l}\text { Starch and flour (pinhão, } \\
\text { Araucaria angustifolia } \\
\text { (Bertol.) Kuntze) }\end{array}$ & $1.14-2.80$ & $1.60-46.5$ & $19-2586$ & $2.80-64.7$ & & & [164] \\
\hline $\begin{array}{l}\text { Starch (ulluco, Ullucus } \\
\text { tuberosus Loz.) }\end{array}$ & $4.14-4.84$ & $10.6-15.1$ & $765.5-1155$ & $4.44-4.95$ & & & [165] \\
\hline $\begin{array}{c}\text { Starch (lentil, Lens culinaris } \\
\text { Medik., flour) }\end{array}$ & $16.1-18.7$ & $2.1-6.3$ & $0.86-4.8$ & $42-149$ & & & [166] \\
\hline $\begin{array}{l}\text { Starch (wheat, Triticum } \\
\text { aestivum L.) }\end{array}$ & 130 & & & & & & [167] \\
\hline $\begin{array}{c}\text { Starch (quinoa, } \\
\text { Chenopodium quinoa Willd.) }\end{array}$ & 450 & 7.56 & 4.59 & 58.14 & $\begin{array}{c}0.5 \times 10^{-13} \\
\left(\mathrm{~cm}^{3} \mathrm{~m}^{-1} \mathrm{~s}^{-1} \mathrm{~Pa}^{-1}\right)\end{array}$ & & [33] \\
\hline $\begin{array}{c}\text { Starch (potato, Solanum } \\
\text { tuberosum L.) }\end{array}$ & 217 & & & & $137.5\left(20^{\circ} \mathrm{C}\right)$ & $2523.7\left(20^{\circ} \mathrm{C}\right)$ & [168] \\
\hline $\begin{array}{l}\text { Starch (tapioca, Manihot } \\
\text { esculenta Crantz) }\end{array}$ & 2.1 & 1.16 & 6.2 & 38 & & & [169] \\
\hline $\begin{array}{l}\text { Starch (cush-cush yam, } \\
\text { Dioscorea trifida L.) }\end{array}$ & 1.8 & 1.88 & 13.9 & 19 & & & [169] \\
\hline Chitosan & & 74.0 & 2451 & 4.60 & & & [170] \\
\hline Chitosan (crustacean shells) & 360 & & & & 0.9 & 15.33 & [171] \\
\hline Chitosan (shrimp shell) & 4.5 & 82.4 & 534 & 5.2 & & & [172] \\
\hline $\begin{array}{l}\text { Gum and protein isolate } \\
\text { (Cajanus cajan (L.) } \\
\text { Millsp. seed) }\end{array}$ & & $0.002-0.046$ & $0.014-0.044$ & $0.74-4.60$ & & & [173] \\
\hline $\begin{array}{l}\text { Starch (corn, Zea mays L.) } \\
\text { and flour (eggplant, } \\
\text { Solanum melongena L.) }\end{array}$ & & $2.36-4.29$ & $42.7-65.5$ & $19.7-37.3$ & & & [174] \\
\hline
\end{tabular}


Table 4. Cont.

\begin{tabular}{|c|c|c|c|c|c|c|c|}
\hline \multirow{2}{*}{ Polysaccharide/Components } & \multirow{2}{*}{$\begin{array}{l}\text { Water Vapour Permeability } \\
\text { (WVP) } \\
\left(10^{-11} \mathrm{~g} \mathrm{~m}^{-1} \mathrm{~Pa}^{-1} \mathrm{~s}^{-1}\right) \\
\text { at } 25^{\circ} \mathrm{C}\end{array}$} & \multirow{2}{*}{$\begin{array}{c}\text { Tensile Strength } \\
\text { (MPa) }\end{array}$} & \multirow{2}{*}{$\begin{array}{c}\text { Young's Modulus } \\
\text { (MPa) }\end{array}$} & \multirow{2}{*}{$\begin{array}{c}\text { Elongation at Break } \\
(\%)\end{array}$} & \multicolumn{2}{|c|}{$\begin{array}{c}\mathrm{O}_{2} / \mathrm{CO}_{2} \text { Permeability } \\
\left(\mathrm{mL} \mu \mathrm{m} /\left(\mathrm{m}^{2} \mathrm{~d} \mathrm{~Pa}\right)\right)\end{array}$} & \multirow[t]{2}{*}{ References } \\
\hline & & & & & $\mathrm{PO}_{2}$ & $\mathrm{PCO}_{2}$ & \\
\hline Methyl cellulose & 7.55 & & & & $1.12\left(30^{\circ} \mathrm{C}\right)$ & $64.19\left(30^{\circ} \mathrm{C}\right)$ & [175] \\
\hline Pectin (citrus peel) & 7.3 & 62 & 1467 & 20 & $\begin{array}{c}10 \\
\left(\mathrm{~cm}^{3} \mathrm{~m}^{-2} \mathrm{~d}^{-1} \mathrm{bar}^{-1}\right) \\
\left(23^{\circ} \mathrm{C}\right)\end{array}$ & $\begin{array}{c}119 \\
\left(\mathrm{~cm}^{3} \mathrm{~m}^{-2} \mathrm{~d}^{-1} \mathrm{bar}^{-1}\right) \\
\left(23^{\circ} \mathrm{C}\right)\end{array}$ & [177] \\
\hline $\begin{array}{l}\text { Pectin (apple) and } \\
\text { glycerol—different \% } \\
\text { composition }\end{array}$ & $1.21-2.25$ & $0.00356-0.00972$ & & $4.9-12.4$ & & & [178] \\
\hline Alginate (sodium alginate) & 7.2 & 39 & 607 & 27 & $\begin{array}{c}438 \\
\left(\mathrm{~cm}^{3} \mathrm{~m}^{-2} \mathrm{~d}^{-1} \mathrm{bar}^{-1}\right) \\
\left(23^{\circ} \mathrm{C}\right)\end{array}$ & $\begin{array}{c}1043 \\
\left(\mathrm{~cm}^{3} \mathrm{~m}^{-2} \mathrm{~d}^{-1} \mathrm{bar}^{-1}\right) \\
\left(23^{\circ} \mathrm{C}\right)\end{array}$ & [177] \\
\hline $\begin{array}{l}\text { Alginate (sodium alginate) } \\
\text { and pectin—different } \% \\
\text { composition }\end{array}$ & $0.84-1.73$ & $22.5-42.3$ & & $5.9-14.9$ & & & [179] \\
\hline
\end{tabular}




\section{Improving Physical Properties of Edible Films and Coatings}

Modification of sensory, nutritional and functional properties, including mechanical properties, of edible coatings, can be obtained by adding various substances. The basic components or matrix components of edible coatings are hydrocolloids (polysaccharides) [59]. The matrix of coatings can be modified with plasticisers (increasing their elasticity and extensibility), emulsifiers or surfactants (improving the stability of the emulsion) and crosslinking agents (improving physical properties). Edible coatings are used directly on fruits and vegetables; hence they can also be carriers of other food additives such as anti-oxidants, nutraceuticals, flavourings, etc., which modify their functional properties [92,180].

Plasticisers are low-molecular, non-volatile compounds, such as monosaccharides, oligosaccharides (glucose, fructose, sucrose, and honey) [5], polyols (glycerol, sorbitol, xylitol, polyethylene glycols) [181-185], lipids and derivatives (phospholipids, fatty acids) $[186,187]$ and clay [188]. The incorporation of these substances into the structure is necessary to obtain flexible coatings. Plasticisers reduce the strength of cohesion by reducing the intermolecular hydrogen bonds between the polymer chains. They cause an increase in intermolecular spaces, thus increasing the mobility of molecules, leading to a decrease in the degree of crystallisation, changes in the tensile strength and changes in Young's modulus $[189,190]$. It has been shown that the plasticiser in contact with a larger number of -OH groups during gelation reduces the tendency of potato starch to crystallise [191]. Plasticisers improve flexibility, workability and elongation and make films and coatings less hard and brittle and prevent them from cracking [59,181,192]. By reducing the intermolecular forces acting between adjacent chains, plasticisers reduce the stiffness and increase the extensibility of polymers $[30,193]$. Although they improve the structural properties of edible films and coatings, they may negatively affect their barrier properties [194], reducing their permeability to gas, water vapour and dissolved substances [195].

Modifications are also used to improve the performance, physical and functional properties of edible films or coatings for fruit and vegetables. Functional properties can be improved, among others by heating, UV and $\gamma$ radiation (physical cross-linking) or crosslinking with lactase and tyrosinase. Cross-linking implies the formation of non-covalent or covalent bonds and aims to develop a three-dimensional network through effective binding of the polymer chain [196]. Irradiation, sulphur vulcanisation or chemical reactions cause chemical cross-linking across the polymer chains. In turn, non-covalent bonding is achieved through ionic interactions, hydrogen bonds or hydrophobic interactions [197]. The use of cross-linking agents in the creation of materials improves their water resistance, cohesion, stiffness, mechanical strength and optical properties, thanks to which edible films and coatings are more effective and long-lasting [198,199]. Cross-linking agents such as cinnamaldehyde [196], glutaraldehyde [200], ferulic acid [201] and sodium trimetaphosphate [202] improve the internal bonding of the films and their functional properties. They cause incomplete disintegration of the film, and when coming into contact with water, they prevent it from dissolving and swelling [196]. In turn, surface-active agents, i.e., surfactants (detackifiers), are in a higher concentration on the surface of the material, affecting the surface tension and wettability of the solution coating food products, e.g., vegetables and fruit. By lowering the surface tension, they facilitate the adhesion of the coating material to the product surface [117]. Their polar part has a strong affinity for polar solvents, and the non-polar part (so-called lipophile) can combine with non-polar solvents. This symmetry between the polar and non-polar parts directs the action of the surfactant at the interface as well as influences the properties of the coating [203]. Surfactants are intended to reduce the overall tackiness of edible films and coatings. Non-ionic surfactants approved for use in food products are tweens (Tween 20, Tween 80 and Tween 85) and spans (Span 80) [204-206].

Composite coatings can be produced as either bilayer or stable emulsions. In bilayer coatings, the lipid forms a second layer over the polysaccharide layer. In emulsion coatings, the lipid is dispersed and entrapped in the supporting matrix of protein or polysaccha- 
ride $[207,208]$. In this type of coatings, the efficiency of lipid materials depends on the lipid structure, its chemical arrangement, hydrophobicity, physical state and its interaction with other components of the film [209].

The functional properties of chitosan-based films can also be improved by adding various polysaccharides [210-212]. The combination of polysaccharides (e.g., starch, alginate, cellulose and chitosan) with proteins (e.g., milk protein, soy protein, collagen and gelatin) in edible films improves their mechanical and physical properties. Laminated chitosan/pectin films are based on the interaction of cationic chitosan groups with anionic pectin groups. Moreover, the films made of chitosan and gelatin are homogeneous due to the good miscibility between the two biopolymers [213-215], which leads to improved functional properties of blended films compared to those obtained from pure polymers. This explains the formation of electrostatic interactions between the ammonium groups of chitosan and the carboxylate groups of gelatin.

\section{Influence of Electric Field on Film Formation}

In recent times, the electric field has become an important tool used by researchers in the field of edible films and coatings. Numerous authors have shown that the use of electric fields promotes a significant improvement in the transport and mechanical properties of edible coatings [150,216-218]. Electric fields processing (e.g., ohmic heating) is based on the passage of electrical current through a product that has an electrical resistance. The electrical energy is thus converted to heat. Instant heating occurs, its magnitude depending on the intensity of the current passing through the food material. The electrical conductivity increases with rising temperature for most food materials, suggesting that ohmic heating becomes more effective as temperature increases, but this could result in runaway heating. Until the present moment, only two methodologies have been tested, which are briefly described below: (1) the application of the electric field to the film-forming solutions with subsequent drying [216,219] and (2) the application of the electric field during the drying process $[218,220]$.

Lei et al. [218] reported advantages in the use of ohmic heating for the production of protein-lipid films, including the improvement of the yield, of the film formation rate and of the rehydration capacity of the films. They concluded that the major advantage of heating is that the heat is dispersed uniformly throughout the whole liquid compared to water bath heating, and finally concluded that the film formation rate was higher when ohmic heating was applied. During the heating process, heat was uniformly applied to the whole volume of the film, accelerating the collisions between molecules. This process can provide an improvement in the crystallinity of the chitosan film, thus increasing the material's resistance to gas permeation. Garcia et al. [220] analysed the effect of applying an electrical field during drying on the microstructure of films formulated with different concentrations of chitosan and methylcellulose. They showed that electric field treatment can be a good alternative to improve the flexibility of the film and increase the water vapour barrier properties. Souza et al. [216] applied a moderate electric field to film-forming chitosan solutions and showed that it influences the physical properties and structure of edible films and coatings, which then translates into their transport properties.

Water vapour permeability (WVP) is an important parameter that is governed by the interactions between the polymer and water molecules. Souza et al. [216] showed that the WVP of chitosan membranes decreased (to 17.3\%) with increasing electric field strength applied to the film-forming solution for values of $100 \mathrm{~V} \cdot \mathrm{cm}^{-1}$ or higher. A positive correlation was found between the WVP and the crystallinity of the film. Balau et al. [221] studied the X-ray difractogram of chitosan films and observed an almost amorphous structure; the films treated with an electric field of $\mathrm{E}=20 \mathrm{kV} \mathrm{cm}^{-1}$ developed a crystalline structure, while the films to which no electric field was applied displayed a significantly lower proportion of crystalline material, showing that the electric field plays an important role in the crystallisation process. Miller and Krochta [222] also pointed to the fact that 
permeability is largely influenced by how tightly the polymer chains are packed, thus establishing a direct relationship between the crystallinity of the structure and permeability.

Park et al. [211] found that the increase in the TS and E values for chitosan films is related to the deacetylation degree of the sample. This is due to the higher crystallinity of the chitosan film, which reduces the absorption of water particles. Garcia et al. [220] showed that electrically treated samples exhibited higher E values, indicating that the electric treatment allowed the alignment of the chains in the field direction, facilitating their stretching and thus increasing their flexibility.

The application of electric fields to solutions forming films and coatings significantly influences their selected properties, which depend on the applied electric field. This means that it is possible to tailor the coatings properties by subjecting them to an electric field of controlled magnitude. In practice, the changes in the film properties induced by the application of the electrical field may translate into an improved shelf life of fruits and vegetables due to reduced water loss (calculated on the basis of the lower WVP) and re-duced $\mathrm{O}_{2}$ and $\mathrm{CO}_{2}$ exchanges. Application of electric fields may provide a novel method for the production of coatings and films with distinctive properties. However, further research is needed for a clearer understanding of the importance of these changes for real food system applications. Despite the many advantages of using an electric field, there are, however, certain barriers (convincing consumers of the new technology, relatively high investment costs), limiting the use of this method on an industrial scale.

\section{Edible Films and Coatings and the Post-Harvest Quality of Vegetables and Fruits}

The application of edible coatings with polysaccharides has a positive effect on the extension of the shelf life of fruits and vegetables and the preservation of their nutritional or sensory properties, preventing microbiological $[22,223]$, chemical and physical processes $[92,224]$. They show special barrier properties, reducing the migration of moisture, oxygen and other gases. The use of edible coatings and their doses are regulated by the laws of the country where the coating is applied or in the country to which fruits and vegetables are to be exported. Selected applications of edible films and coatings on various fruits and vegetables in order to improve their quality are presented in Table 5. 
Table 5. Effect of edible films and coatings on the quality of fruits and vegetables.

\begin{tabular}{|c|c|c|c|c|c|}
\hline Polysaccharide/Components & Coated Fruit/Vegetable & Microbiological Stability & Chemical Stability & Physical Stability & References \\
\hline Alginate/nano-Ag & $\begin{array}{l}\text { Shiitake mushroom (Lentinula } \\
\text { edodes (Berk.) Pegler) }\end{array}$ & $\begin{array}{l}\text { Beneficial effect against fungal } \\
\text { infection }\end{array}$ & $\begin{array}{l}\text { Increase in reducing sugar, total } \\
\text { sugar, total soluble solids and } \\
\text { electrolyte leakage rate }\end{array}$ & $\begin{array}{l}\text { Improvement of sensory } \\
\text { attributes and decrease in weight } \\
\text { loss, softening and browning }\end{array}$ & [225] \\
\hline $\begin{array}{c}\text { Alginate/ascorbic acid/citric } \\
\text { acid }\end{array}$ & Mango (Mangifera L.) & - & $\begin{array}{l}\text { Increase in antioxidant activity } \\
\text { and vitamin C }\end{array}$ & Retention of colour & [227] \\
\hline $\begin{array}{l}\text { Alginate/cellulose nanofibril } \\
\text { (CNF) }\end{array}$ & $\begin{array}{l}\text { Andean blueberry (Vaccinium } \\
\text { meridionale Swartz): }\end{array}$ & - & Retention of soluble solids & $\begin{array}{l}\text { Retention of firmness; decrease in } \\
\text { respiration rate and the water } \\
\text { loss; prevention of cell wall } \\
\text { degradation }\end{array}$ & [228] \\
\hline $\begin{array}{l}\text { Alginate/chitosan/Flourensia } \\
\text { cernua extract/nanolaminate } \\
\text { (layer-by-layer coating) }\end{array}$ & Tomato (Solanum lycopersicum L.) & $\begin{array}{c}\text { Beneficial effect against } \\
\text { bacterial and fungal infection }\end{array}$ & & $\begin{array}{c}\text { Decrease in weight loss, ethylene } \\
\text { production and oxygen and } \\
\text { carbon dioxide gas exchange } \\
\text { rates; retention of firmness and } \\
\text { colour; } \\
\text { stopped growth in headspace }\end{array}$ & [229] \\
\hline Alginate/rhubarb extract & Peaches (Prunus persica L.) & $\begin{array}{l}\text { Beneficial effect against fungal } \\
\text { infection (Penicillium expansum) }\end{array}$ & $\begin{array}{l}\text { Decrease in maleic dialdehyde } \\
\text { content and polyphenol } \\
\text { oxidase activity; retention of } \\
\text { soluble solids }\end{array}$ & $\begin{array}{l}\text { Decrease in weight loss and } \\
\text { respiration rate; retention of } \\
\text { firmness }\end{array}$ & [231] \\
\hline Carrageenan/glycerol & Papaya (Carica papaya L.) & & & $\begin{array}{l}\text { Reduction in moisture loss; } \\
\text { delayed ripening; retention of } \\
\text { firmness }\end{array}$ & [232] \\
\hline $\begin{array}{l}\text { Carrageenan/ascorbic } \\
\text { acid/citric acid/oxalic } \\
\text { acid } / \mathrm{CaCl}_{2}\end{array}$ & Apple (Malus Mill.) & $\begin{array}{l}\text { Beneficial effect against fungal } \\
\text { infection }\end{array}$ & Increase in antioxidant activity & Retention of colour and firmness & [233] \\
\hline $\begin{array}{c}\text { Agar/ k-carrageenan/konjac } \\
\text { glucomannan }\end{array}$ & Spinach (Spinacia oleracea L.) & $\begin{array}{l}\text { Beneficial antibactericidal effect } \\
\text { (Listeria monocytogenes) }\end{array}$ & & & [234] \\
\hline Agar/chitosan/acetic acid & Garlic (Allium sativum L.) & $\begin{array}{l}\text { Beneficial effect against fungal } \\
\text { infection }\end{array}$ & & $\begin{array}{l}\text { Retention of colour and } \\
\text { reduction in respiration rate }\end{array}$ & [235] \\
\hline
\end{tabular}


Table 5. Cont

\begin{tabular}{|c|c|c|c|c|c|}
\hline Polysaccharide/Components & Coated Fruit/Vegetable & Microbiological Stability & Chemical Stability & Physical Stability & References \\
\hline Chitosan & Banana (Musa spp.) & $\begin{array}{c}\text { Beneficial effect against fungal } \\
\text { infection (Colletotrichum musae, } \\
\text { Fusarium spp., Lasiodiplodia } \\
\text { theobromae) }\end{array}$ & Retention of soluble solids & $\begin{array}{l}\text { Delayed ripening and retention } \\
\text { of peel colour and firmness }\end{array}$ & [236] \\
\hline Chitosan & - & $\begin{array}{l}\text { Beneficial effect against fungal } \\
\text { infection (Aspergillus niger) }\end{array}$ & & & [237] \\
\hline Chitosan & Peach (Prunus persica (L.) Batsch) & $\begin{array}{l}\text { Beneficial effect against fungal } \\
\text { infection (Monilinia fructicola) }\end{array}$ & $\begin{array}{c}\text { Increase in titratable acidity } \\
\text { and vitamin } C\end{array}$ & $\begin{array}{l}\text { Delayed ripening and senescence; } \\
\text { retention of firmness; reduction } \\
\text { in respiration rate and ethylene } \\
\text { and malondialdehyde } \\
\text { production; higher superoxide } \\
\text { dismutase activity; better } \\
\text { membrane integrity }\end{array}$ & [238] \\
\hline $\begin{array}{c}\text { Chitosan/Ficus hirta Vahl. fruit } \\
\text { extract }\end{array}$ & $\begin{array}{c}\text { Xinyu tangerine (Citrus reticulata } \\
\text { Blanco) }\end{array}$ & $\begin{array}{l}\text { Beneficial effect against fungal } \\
\text { infection (Penicillium italicum) }\end{array}$ & $\begin{array}{l}\text { Increase in reduction of soluble } \\
\text { solids; increase in titrable acid } \\
\text { and ascorbic acid content; } \\
\text { decrease in malondialdehyde } \\
\text { content; increased activities of } \\
\text { superoxide, dismutase, } \\
\text { peroxidase and phenylalanine } \\
\text { ammonia-lyase }\end{array}$ & $\begin{array}{l}\text { Reduced fruit decay rate, weight } \\
\text { loss and respiration rate }\end{array}$ & [239] \\
\hline Chitosan/Laurus nobilis extract & $\begin{array}{c}\text { Cashew nut } \\
\text { (Anacardium occidentale L.) }\end{array}$ & $\begin{array}{c}\text { Beneficial effect against } \\
\text { bacterial and fungal infection }\end{array}$ & Delay in lipid oxidation & & [240] \\
\hline $\begin{array}{l}\text { Beeswax/chitosan/beeswax } \\
\text { (three-layer coatings) }\end{array}$ & $\begin{array}{c}\text { Strawberries (Fragaria } \times \text { ananassa } \\
\text { Duchesne) }\end{array}$ & $\begin{array}{l}\text { Beneficial effect against fungal } \\
\text { infection }\end{array}$ & $\begin{array}{l}\text { Retention of titratable acidity, } \\
\mathrm{pH} \text {, soluble solids and reducing } \\
\text { sugars }\end{array}$ & $\begin{array}{l}\text { Decrease in senescence, weight } \\
\text { loss and respiration rate; } \\
\text { retention of firmness, colour and } \\
\text { texture of tissue }\end{array}$ & [241] \\
\hline Chitosan/chlorogenic acid & Peach (Prunus persica L.) & & $\begin{array}{l}\text { Enhancement of antioxidant } \\
\text { activity; retention of titratable } \\
\text { acidity, soluble solid content } \\
\text { and L-ascorbic acid content; } \\
\text { reduced ROS levels }\end{array}$ & $\begin{array}{l}\text { Decrease in weight loss and } \\
\text { respiration rate and retention of } \\
\text { firmness }\end{array}$ & [242] \\
\hline Chitosan/oxidised starch & Papaya (Carica papaya L.) & $\begin{array}{l}\text { Beneficial effect against } \\
\text { bacterial and fungal infection }\end{array}$ & & Retention of firmness & [243] \\
\hline
\end{tabular}


Table 5. Cont.

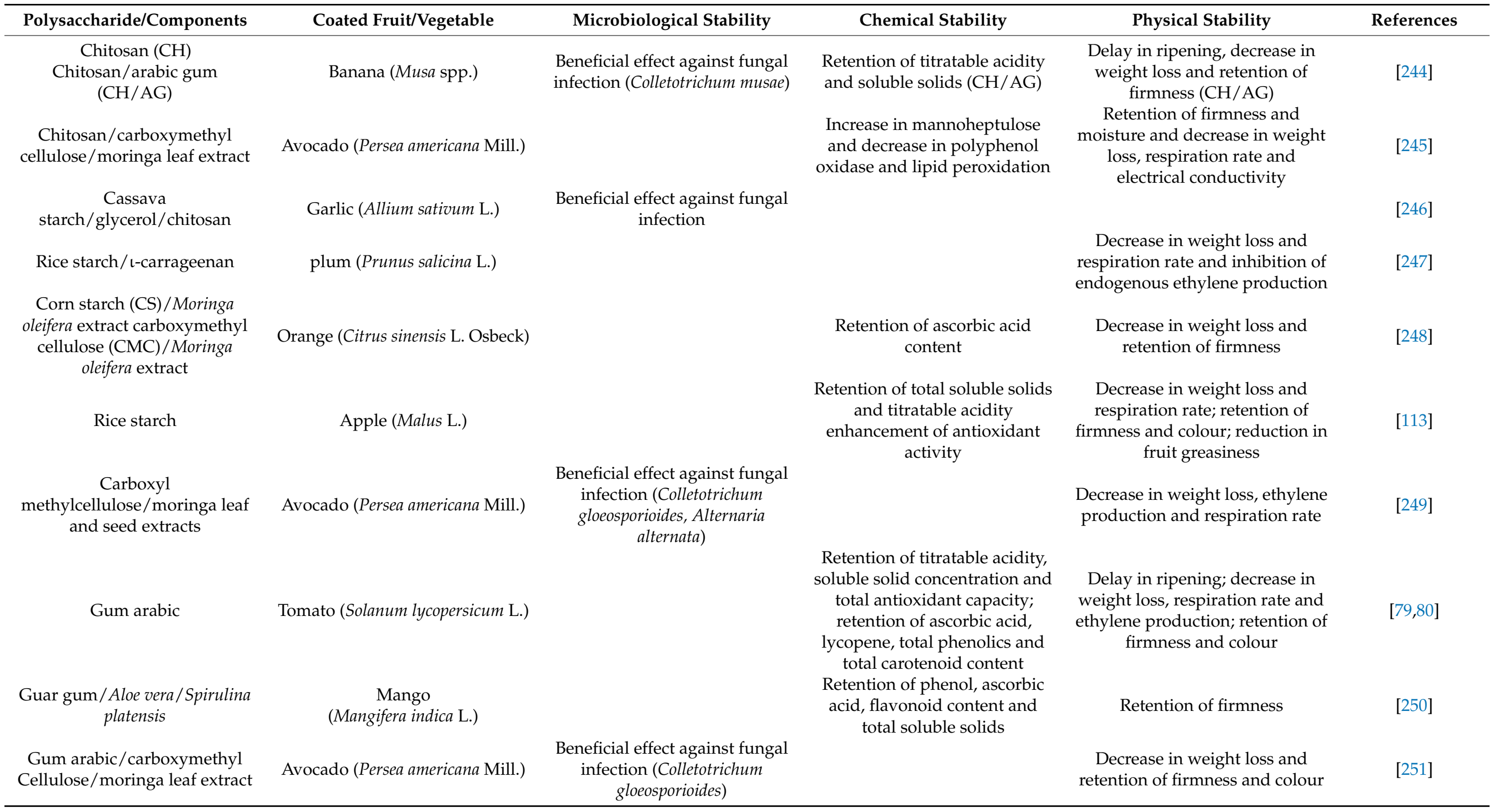


The presence of pathogenic microorganisms contributes to a number of undesirable changes in fruits and vegetables. Bnuyan et al. [252] reported that gum arabic exhibited good antimicrobial activity against various bacteria and fungi, including S. aureus, S. epidermidis, S. pneumoniae, Ps. aeruginosa, P. mirabilis, Acinetobacter, Enterobacter, Klebsiella pneumoniae, Serratia spp., E. coli, Salmonella typhi and C. albicans. Gum arabic coating has been successfully used for preserving the quality and safety of apples during cold storage. The coating significantly reduced decay compared to uncoated samples of apples [253]. In addition, other studies have confirmed that using gum arabic as packaging materials effectively inhibits fungal growth during storage in perishable food such as strawberries [254] or tomatoes [79].

Edible coatings with alginate can reduce weight loss, preserve the quality of apples and prolong their shelf-life [255]. Edible coatings based on gums create a modified atmosphere around the fruit by providing a semi-permeable barrier to $\mathrm{CO}_{2}$ and $\mathrm{O}_{2}$, thus decreasing respiration and oxidation reaction rates [256]. Amanatidou et al. [257] investigated the high $\mathrm{O}_{2}$ - and high $\mathrm{CO}_{2}$-modified atmospheres for increasing the shelf life of carrots. Their results showed that edible coatings with alginate gum can decrease weight loss and natural microbial total counts in carrots. The influence of edible coating based on alginate gum (1\% and $3 \%$ ) on preserving plum quality during post-harvest storage was studied by Valero et al. [258]. The treatments were useful in inhibiting ethylene production, especially when $3 \%$ alginate was used. The delay in the ripening process was related to lower carotenoid and anthocyanin accumulation. The changes in fruit quality parameters related to plum post-harvest ripening, including weight and acidity losses, softening and colour changes, were delayed by the use of alginate edible coatings. Edible films and coatings can preserve the quality of tomatoes by functioning as solute, vapour and gas barriers. Zapata et al. [162] investigated alginate-based edible coatings on tomato to delay the post-harvest ripening process and to maintain its quality. Their results showed positive effects of retarding the ripening process by decreasing the respiration rate and ethylene production, and changes triggered by this plant hormone, such as colour change and loss of firmness [256].

Pigeon pea polysaccharide combined with protein isolate provided a good semipermeable barrier around strawberry fruit, which decreased the change in acidity, $\mathrm{pH}$, soluble solids, weight loss and firmness loss [173]. In the food industry, a combination of starch and gums is used to modify and control texture, improve moisture retention and control water mobility [259]. Guar gum and pea starch edible coatings provided effective control in ethylene production, respiration rate and weight and firmness loss [260]. In peach fruit, tara gum treatments produced a good effect on weight loss reduction, firmness conservation and maintenance of greater total soluble solids [261]. Specifically, the composite coating agent consisted of tara gum, ascorbic acid, citric acid, calcium chloride and glycerol, making it possible to improve the mechanical barrier properties of the edible coatings. Gum arabic and chitosan-based edible coatings are effective post-harvest treatments to conserve the quality of banana fruit during cold storage.

Coating technology is a promising approach in order to prolong the consumer acceptability and shelf life of fruits and vegetables. The composites are able to control the growth of microorganisms, increase antioxidant activity, retain soluble solids, decrease weight loss, retain colour and control the concentration of ethanol [244,262,263]. In general, edible films and coatings should be safe, biodegradable and non-toxic to fruits and vegetables.

\section{Application of Functional Substances in Innovative Edible Films and Coatings}

Edible films and coatings are a rapidly evolving technology that provides an alternative to conventional plastics that seriously pollute the environment. The main advantages of environmentally friendly composites are that they are renewable and biodegradable. Therefore, recently the development of edible coatings has attracted more and more attention from researchers and consumers, mainly due to the wide variety of applications these materials provide. Much research is focused on the development and testing of new materials where the new components are used as coatings. These materials may 
be available food compounds that exist but have not been tested as edible packaging ingredients or industrial by-products and waste that find sustainable use [14]. Fruit and vegetable residues as components of polysaccharide coatings have been the subject of much research $[120,157,264]$. These residues are a rich source of nutrients and bioactive compounds, especially biopolymers such as polysaccharides and dietary fibre. In addition, the peel, pomace and seed fractions of some fruits have higher antioxidant activity than the pulp fractions. Recently, attention has also been paid to the use of fruit and vegetable residues in the preparation of edible films and coatings. Andrade et al. [265] investigated new edible coatings based on flour from various residues, including orange, passion fruit, watermelon, lettuce, zucchini, carrot, mint, cucumber and arugula. The authors obtained homogeneous, flexible films without the addition of plasticisers, which showed promising properties. Another good example is the use of citrus fruit by-products. Grapefruit albedo was investigated as a film-forming material, showing good functional properties of the produced films [266] and pomelo peel flour [267]. Plant residues are complex materials and therefore different residues fractions can have different uses, depending on their composition and particle size (as dietary fibre, as major components of edible films and coatings). Research by Riaz [268] focused on the use of Opuntia cactus as a potential application in improving the shelf life of citrus. The polysaccharides extracted from the Opuntia cactus were applied to the citrus fruit in the form of an edible coating and stored for up to 35 days at $5{ }^{\circ} \mathrm{C}$ and $90 \%$ relative humidity. The results indicated that the edible cactus coating extended the shelf life of the mandarin. Like polysaccharides, waste or by-products used in the preparation of edible coatings are also environmentally friendly and economical and have promising film-forming properties.

Increasingly, herbal extracts are also being investigated as an additive to polysaccharide edible films and coatings. This may become their innovative and alternative commercial application in the post-harvest processing of fruits and vegetables, extending their shelf life. Herbs are a natural source of vitamins, minerals and antioxidants, which are beneficial for health and act as nutraceuticals and medicines. Edible coatings are made from herbs or a combination of other edible coatings and herbs, and the most common herbs used in edible coatings are Aloe vera gel, lemongrass, rosemary, tulsi and turmeric $[1,64,127,269,270]$. The $10 \%$ extracts of garlic and ginger inhibited most of the bacterial and fungal isolates except for Rhizopus and Aspergillus [271]. A significantly lower physiological loss in weight (PLW) percentage was recorded in tomato fruit sprayed with $10 \%$ garlic extract followed by spraying of $10 \%$ ginger extract. The use of natural antimicrobials such as herbal extracts enhances the shelf-life of fresh-cut tomatoes, maintaining or increasing the contents of lycopene, ascorbic acid and total phenolic compounds [272]. The use of plant extracts could be a useful alternative to synthetic fungicides in the management of rot fungi during post-harvest handling of fruits and vegetables. A new approach to the control of post-harvest pathogens, while maintaining fruit quality, has been implemented by the application of essential oils. This approach eliminates the need for synthetic fungicides, thereby complying with consumer preferences and organic requirements and reducing environmental pollution [273]. The antimicrobial activity of essential oils is attributed to the presence of compounds with characteristic chemical structures, in particular to the presence of hydrophilic functional groups, such as hydroxyl groups of phenolic components, and/or the lipophilicity of some essential oil components [274]. Usually, compounds with phenolic groups, such as oils of clove, oregano, rosemary, thyme, sage and vanillin, are the most effective. These are more inhibitory against Gram-positive than Gram-negative bacteria [275]. Ginger, mint and clove bud oil, turmeric extract and other essential oils and extracts are also used in edible coatings of fruit and vegetables [276,277].

Much attention has been paid to enhancing and improving the antimicrobial properties of edible coatings materials. Fruits and vegetables are sources of various disease outbreaks [278]; however, their susceptibility to microbial contamination is attributed to their high moisture content and nutrients, which provide an excellent environment for the growth of pathogenic microorganisms (bacteria, moulds and yeasts). The microbial 
contamination of fruits and vegetables can occur during harvesting, packaging, processing, transportation, distribution and storage. For instance, Salmonella spp., Escherichia coli (O157: H7), Staphylococcus aureus, Campylobacter spp. and Listeria monocytogenes are the pathogens most implicated in many human diseases $[279,280]$. In addition to its effectiveness as a mechanical barrier, edible polysaccharide treatment can be applied for its antimicrobial activities to maintain the quality of produce and prolong its post-harvest shelf life [254]. A study indicated that the phenolic hydroxyl group in plant polyphenols can interact with carboxyl groups of polysaccharides [281]. This type of interaction can slow the release of bioactive ingredients from films and coatings and ultimately improve the antimicrobial properties of the coatings. Guar gum in combination with bioactive substances from natural raw materials (black cumin seeds, coriander seeds, bay leaf, fennel seeds) reduced the total viable count in tomato fruit up to 60 days at $10^{\circ} \mathrm{C}$ [282]. The addition of lemongrass essential oil to linseed gum improved the antibacterial effect of pure linseed gum [283]. Maqbool et al. [262] investigated the antifungal effects of gum arabic containing lemongrass oil and cinnamon oil to combat banana and papaya bacteria. The results showed that the use of gum arabic with essential oils successfully reduces the growth of Colletotrichum musae and Colletotrichum gloeosporioides in tropical fruit. However, it should be remembered that a large addition of essential oils may improve the antimicrobial effect but may also have a negative taste of the coated material.

Another environmentally friendly approach is the use of nanoemulsions. A nanoemulsion is defined as a conventional emulsion with a particle size ranging from 1 to $100 \mathrm{~nm}$. The entrapment of naturally occurring substances with functional properties, into nanoemulsions enables the development of edible coatings with antimicrobial properties and hence proves better than conventional emulsions. During cold storage studies of the shelf life of rucola leaf, it was found that the shelf life was prolonged for 7 days using edible coatings formed with nanoemulsions prepared by a combination of lipophilic and hydrophilic combined surfactants (glycerol monooleate and Tween 20) with lemon oil and water added to a chitosan solution. Nanoemulsion-based coatings exhibited better shelf life than lemon oil or chitosan coatings alone [284]. Similarly, carvacrol-incorporated nanoemulsions with modified chitosan solutions completely inhibited Escherichia coli growth on fresh green beans over 11 days of cold storage [285].

Polysaccharide films and coatings have also been found to be a suitable medium for the synthesis and stabilisation of silver nanoparticles $[286,287]$. This type of polymerassisted synthesis route ensures a good dispersion of nanoparticles in the polymer matrix, which, in turn, affects the final structural stability and homogeneity of the nanocomposite coating, leading to the preservation of strong antimicrobial properties in nanocomposite films $[147,288]$. Bankura et al. [286] discovered that dextran, a polymer with promising properties when used as edible films and coatings, could be a medium for the synthesis of silver nanoparticles with a size of about $10-60 \mathrm{~nm}$. Silver nanoparticles are well covered with dextran particles, thanks to which they can attach to the hydroxyl group of dextran molecules, which prevents their aggregation. The resulting systems show effective antibacterial activity against B. subtilis, B. cereus, E. coli, S. aureus and P. aeruginosa. Lin et al. [289] showed that silver nanoparticles in chitosan matrices showed good dispersion without agglomeration for almost three months. The strong affinity between the polymer matrix and the metal particles corresponds to the amino and hydroxyl groups of chitosan. As a result, the effective antibacterial activity of such nanocomposite materials against both Gram-positive and Gram-negative bacteria was observed. In research conducted by Bahrami et al. [290], an innovative three-layer biocomposite film based on tragacanth/hydroxypropylmethylcellulose/beeswax enhanced and enriched with silver nanoparticles (AgNP) was developed. The influence of $\mathrm{AgNP}(2 \%, 4 \%$ and $8 \%)$ on some physical-mechanical and antibacterial properties of the biocomposite film was investigated. AgNP was found to lower the tensile strength of the composite. However, the water vapour permeability was improved by adding nanoparticles $\left(4.57-2.16 \times 10-13 \mathrm{~g} / \mathrm{m}^{2} \mathrm{sPa}\right)$. The tested nanocomposite films also showed a strong antibacterial effect on the tested 
pathogenic bacteria. Mohammed Fayaz et al. [291] found that a thin coating of sodium alginate with silver nanoparticles showed good antibacterial activity against the test strains. This film extends the shelf life of carrots and pears compared to the control for weight loss and soluble protein content. These results show that vegetables and fruit coated with sodium alginate with the addition of silver nanoparticles are suitable for preservation. In addition, the storage temperature of nanocomposite materials plays an important role as it may limit their antimicrobial stability. Khalaf et al. [292] investigated the inhibitory potency of pullulan-based membranes containing silver nanoparticles on S. aureus and $L$. monocytogenes during 7 weeks of storage. The authors showed that temperatures higher than $25^{\circ} \mathrm{C}$ significantly reduced the bactericidal activity of nanomaterials. The inclusion of silver nanoparticles into the polymer network of polysaccharides leads to changes in their final structure and affects the physical and mechanical properties of the edible film. However, it is still necessary to study the mechanism of migration of silver nanoparticles from the packaging material to the raw material and their impact on the human body and the natural environment.

\section{Economic Effects of Using Edible Polysaccharide Films and Coatings}

Due to the serious global problem of environmental pollution, the so far quite common plastic packaging for fruit and vegetables is being replaced by new, environmentally friendly solutions. In developed countries, the packaging market is regulated by the European Commission (EC) or the Food and Drug Administration (FDA), where there is pressure to reduce traditional plastic packaging and replace it with more sustainable packaging solutions that include edible films/coatings. At the same time, countries' economies should move from a linear model to a circular economy [293].

In addition to its traditional role, packaging also serves as a communication and branding medium. As a marketing tool, it allows to promote a healthier lifestyle and thus influences the change of consumer habits $[294,295]$. However, it has been shown that the cost of producing bio-packaging from residues can be up to three to five times more expensive compared to packaging made of fossil-based materials [296]. The increase in these costs is related to mobilisation issues of biomass, lack of technological innovations and low economies of scale $[297,298]$. In addition, FDA and EU regulations are associated with restrictions in the implementation of standards, including the support needed for biowaste food packaging materials, appropriation of standards for bioproducts and contact with food and the availability of proper waste management facilities, which is an obstacle in the production of packaging based on biomaterials, including polysaccharides [296]. In addition, to be acceptable to consumers, edible films and coatings should be non-toxic and have a good appearance, lack of aroma and taste (or agreeable taste) and good barrier properties; should prevent the loss of turgor (water loss) and the development of storage diseases of fruits and vegetables and have good stability over time; and, above all, should be economically viable [299]. However, the overall performance and cost of producing edible films have always been a challenge [300]. Moreover, the profitability of using edible films or coatings depends on the type of material from which they are made and the production technology used.

There are also problems with the production of edible films on an industrial scale and their commercialisation for successful packaging of fruit and vegetables. It has been found that the current production of edible films on a laboratory scale may not be suitable for scaling up to the industrial scale as there may be problems related to the inability to produce continuous films, long drying times, inaccurate thickness control, high energy consumption and high costs. Improvement of the functional properties of edible films can be achieved through the use of nanotechnology; however, research is needed towards the use of nanomaterials and their toxicological effects. In addition, insufficient legal aspects, fear of toxicological and health effects, inadequate marketing, social awareness and cultural issues may also contribute to lower consumer acceptance of edible films. Therefore, these 
aspects should be improved, which will undoubtedly facilitate the commercialisation of these biodegradable films [301].

\section{Legislation}

Polysaccharide coatings and edible films are an integral part of fruit and vegetables and therefore are subject to the same legal regulations as other substances in food production [302]. If a material has been approved by the Food and Drug Administration (FDA) as safe and listed as GRAS, and is also used in accordance with Good Manufacturing Practices (GMP), then it can be used in edible packaging. If the biopolymer material used is not currently covered by GRAS, the producer who wants to use it for production may apply for it, provided that its safety can be proved. The toxicity and allergenicity of edible films and coatings should also be taken into account. This especially applies to the use of essential oils used in edible coatings as an antimicrobial compound, although classified and registered by the European Commission and as GRAS, they may show allergenic effects. Consuming higher doses of these natural compounds can lead to toxicity problems. Therefore, it is necessary to find a balance between the effectiveness of the dose of an oil or plant extract and the risk of its toxicity [303]. In addition, edible films and coatings may contain a number of nutrients or functional additives (antioxidants, antimicrobials, colourings, etc.). In the regulation of most countries, chemical substances added as antimicrobials are regarded as food additives if the primary purpose of the substances is shelf-life extension. The use of edible coatings and their doses are regulated by the laws of the country where the coating is applied or in the country to which fruits and vegetables are to be exported. In general, as edible films and coatings become an integral part of fruits and vegetables, all materials used must be properly declared on the label [14,304].

The development of edible films based on pectin and other biodegradable polymers is encouraged by green-packing initiatives such as the US Environmental Protection Agency's (EPA) suggested plan to reduce the initial amount of packaging. The suggestion consisted of designing a packaging system that could reduce the amount of environmental toxic materials used in packaging and make them easier to reuse or compost. The agency also suggested using packaging that could reduce the amount of damage or spoilage to food products, which eventually could improve the quality and extend the shelf life of packaged foods [305].

Generally, edible coatings are safe and biodegradable, with nontoxic influence on the biological system. However, some authors have reported the negative effect of carrageenan gum. These adverse effects are associated with decomposed carrageenan (poligeenan), which have low molecular weights, less than $50 \mathrm{kDa}$ [306-308]. In another study, Tobacman [309] observed the carcinogenic effects of undegraded carrageenans. These adverse effects of carrageenans do not occur when food-grade ingredients (i.e., molecular weight greater than 100,000 Da) are used in edible coatings and films [34,308].

\section{Conclusions and Future Prospects}

Edible films and coatings can be used to extend the shelf life and freshness of fruit and vegetables. Most fruits and vegetables require protection against decay or spoilage during storage. Consumers demand fresh and safe natural commodities. This prompts scientists to look for new post-harvest techniques that will improve the shelf life, quality and safety of fruit and vegetables without causing loss of nutrients and organoleptic properties. Therefore, natural compounds are of great importance in research and industry because of their potential to provide quality and safety benefits with reduced side effects on human health. Numerous studies show that natural polysaccharides are well suited for use as packaging material in fresh fruit and vegetables and can often be an important alternative to synthetic compounds. Natural polymer materials are a good barrier to oxygen and carbon dioxide; however, they are characterised by excessive solubility in the water environment, water vapour permeability and low extensibility. Therefore, edible films and coatings derived from polysaccharides should be modified. Replacing synthetic films with edible 
or biodegradable coatings is desirable from an environmental point of view. A promising trend in this area is the use of nanoemulsions based on polysaccharides or essential oils, with the inclusion of bioactive ingredients or encapsulated nanocoatings, which can also inhibit the growth of pathogenic microorganisms. The use of polysaccharides for the preparation of edible films and coatings is justified not only by the possibility of reducing the consumption of packaging made of synthetic polymer materials but also by the fact that the production of some natural polymers can be made using waste products generated during the processing of food raw materials. Natural edible polysaccharide coatings represent a promising approach to improve the quality and extend the shelf life of fruits and vegetables.

Author Contributions: A.K. and K.K.; writing—original draft preparation, A.K., K.K., K.P., M.S., E.S.-K. and P.H.; writing—review and editing, A.K., K.K., K.P., M.S. and E.S.-K.; supervision, A.K. All authors have read and agreed to the published version of the manuscript.

Funding: This research received no external funding.

Data Availability Statement: The study did not report any data.

Conflicts of Interest: The authors declare no conflict of interest.

\section{References}

1. Raghav, P.K.; Agarwal, N.; Saini, M. Edible coating of fruits and vegetables: A review. Int. J. Res. Mod. Edu. 2016, 1, 2455-5630.

2. Mahajan, B.V.C.; Tandon, R.; Kapoor, S.; Sidhu, M.K. Natural Coatings for Shelf-Life Enhancement and Quality Maintenance of Fresh Fruits and Vegetables-A Review. J. Postharvest Technol. 2018, 6, 12-26.

3. Radev, R.; Pashova, S. Application of Edible Films and Coatings for Fresh Fruit and Vegetables. Qual. Access Success 2020, $21,108-112$.

4. Swathi, V.; Gladvin, G.; Babitha, B. Physico-chemical charectristics and applications of edible films for fruit preservation. Int. Res. J. Eng. Tech. 2017, 4, 1954-1958.

5. Sharma, P.; Shehin, V.P.; Kaur, N.; Vyas, P. Application of edible coating on fresh and minimally processed vegetables: A review. Int. J. Veg. Sci. 2019, 25, 295-314. [CrossRef]

6. Kozłowicz, K.; Sułkowska, M.; Kluza, F. Edible coatings and its impact on quality and durability of fruit and vegetables. Acta Sci. Pol. Tech. Agrar. 2011, 10, 35-45.

7. Dhaka, R.; Upadhyay, A. Edible films and coatings: A brief overview. Pharma Innov. J. 2018, 7, 331-333.

8. Guilbert, S.; Gontard, N.; Gorris, L.G.M. Prolongation of the Shelf-life of Perishable Food Products using Biodegradable Films and Coatings. LWT Food Sci. Technol. 1996, 29, 10-17. [CrossRef]

9. Pajak, P.; Fortuna, T.; Przetaczek-Rożnowska, I. Protein and polysaccharide-based edible packagings: Profile and applications. Food Sci. Technol. Qual. 2013, 2, 5-18. [CrossRef]

10. Park, H.J. Development of advanced edible coatings for fruits. Trends Food Sci. Technol. 1999, 10, 254-260. [CrossRef]

11. Erkmen, O.; Barazi, A.O. General characteristics of edible flms. J. Food Biotechnol. Res. 2018, 2, 1-4.

12. Okcu, Z.; Yavuz, Y.; Kerse, S. Edible films and coatings application in fruits and vegetables. Alinteri J. Agric. Sci. 2018, 33, 221-226. [CrossRef]

13. Oms-Oliu, G.; Rojas-Graü, M.A.; González, L.A.; Varela, P.; Soliva-Fortuny, R.; Hernando, M.I.H.; Munuera, I.P.; Fiszman, S.; Martín-Belloso, O. Recent approaches using chemical treatments to preserve quality of fresh-cut fruit: A review. Postharvest Biol. Technol. 2010, 57, 139-148. [CrossRef]

14. Galus, S.; Kibar, E.A.A.; Gniewosz, M.; Kraśniewska, K. Novel Materials in the Preparation of Edible Films and Coatings-A Review. Coatings 2020, 10, 674. [CrossRef]

15. Shukla, P.; Bhise, S.; Thind, S.S. Role of biodegradable edible films and coatings in food industry. Acta Sci. Nutr. Health 2019, 3, 138-147.

16. Salgado, P.R.; Ortiz, C.M.; Musso, Y.S.; Di Giorgio, L.; Mauri, A.N. Edible films and coatings containing bioactives. Curr. Opin. Food Sci. 2015, 5, 86-92. [CrossRef]

17. Tharantharn, R.N. Biodegradable films and composite coatings: Past, present and future. Trends Food Sci. Technol. 2003, 14, 71-78. [CrossRef]

18. Mohamed, A.Y.E.; Aboul, A.H.E.; Hassan, A.M. Utilisation of edible coating in extending the shelf life of minimally processed prickly pear. J. Appl. Sci. Res. 2013, 9, 1202-1208.

19. Vaishali Sharma, H.P.; Shami, V.; Samsher; Chandhary, V.; Sunil; Kumar, M. Importance of edible coating on fruits and vegetables: A review. J. Pharmacogn. Phytochem. 2019, 8, 4104-4110.

20. Fu, Z.; Wang, L.; Li, D.; Wei, Q.; Adhikari, B. Effects of high-pressure homogenization on the properties of starch-plasticizer dispersions and their films. Carbohydr. Polym. 2011, 86, 202-207. [CrossRef]

21. Basiak, E.; Galus, E.; Lenart, E. Starch films and coatings for food. Food Ind. 2012, 66, 28-30. 
22. Galus, S.; Lenart, A. Effect of coating on food quality. Technol. Prog. Food Process. 2019, 2, 106-114.

23. Skurtys, O.; Acevedo, C.; Pedreschi, F.; Enrione, J.; Osorio, F.; Aguilera, J.M. Food Hydrocolloid Edible Films and Coatings; Nova Science Publishers Inc.: New York, NY, USA, 2010.

24. Coma, V.; Martial-Gros, S.; Gareau, S.; Copinet, A.; Salin, F.; Dechamps, A. Edible antimicrobial films based on chitosan matrix. J. Food Sci. 2002, 67, 1162-1169. [CrossRef]

25. Cisneros-Zevallos, L.; Krochta, J.M. Dependence of coating thickness on viscosity of coating solution applied to fruits and vegetables by dipping method. J. Food Sci. 2003, 68, 503-510. [CrossRef]

26. Falguera, V.; Quintero, J.P.; Jimenez, A.; Munoz, A.; Ibarz, A. Edible films and coatings: Structures, active functions and trends in their use. Trends Food Sci. Technol. 2011, 22, 291-303. [CrossRef]

27. Ghanbarzadeh, B.; Almasi, H.; Entezami, A.A. Physical properties of edible modified starch/carboxymethyl cellulose films. Innov. Food Sci. Emerg. Tech. 2010, 11, 697-702. [CrossRef]

28. Fishman, M.L.; Coffin, D.R.; Onwulata, C.I.; Konstance, R.P. Extrusion of pectin and glycerol with various combinations of orange albedo and starch. Carbohydr. Polym. 2004, 57, 401-413. [CrossRef]

29. Liu, Z. Edible films and coatings from starches. In Innovations in Food Packaging; Han, J.H., Ed.; Academic Press: London, UK, 2005; pp. 318-337. [CrossRef]

30. Basiak, E.; Lenart, A. Starch coatings used in food packaging industry. Food Sci. Technol. Qual. 2013, 1, $21-31$.

31. Espitia, P.J.P.; Avena-Bustillos, R.J.; Du, W.-X.; Chiou, B.-S.; Williams, T.G.; Wood, D.; McHugh, T.H.; Soares, N.F.F. Physical and antibacterial properties of acai edible films formulated with thyme essential oil and apple skin polyphenols. J. Food Sci. 2014, 79, M903-M910. [CrossRef]

32. Hall, D.J. Edible coatings from lipids, waxes, and resins. In Edible Coatings and Films to Improve Food Quality, 2nd ed.; Baldwin, E.A., Hagenmaier, R., Bai, J., Eds.; CRC Press: Boca Raton, FL, USA, 2012; pp. 79-101.

33. Araujo-Farro, P.C.; Podadera, G.; Sobral, P.J.A.; Menegalli, F.C. Development of films based on Quinna (Chenopodium quinoa, Willdenow) starch. Carbohyd. Polym. 2010, 81, 839-848. [CrossRef]

34. Tavassoli-Kafrani, E.; Shekarchizadeh, H.; Masoudpour-Behabadi, M. Development of edible films and coatings from alginates and carrageenans. Carbohydr. Polym. 2016, 137, 360-374. [CrossRef] [PubMed]

35. Glicksman, M. Utilization of seaweed hydrocolloids in the food industry. Hydrobiologia 1987, 151-152, 31-47. [CrossRef]

36. Lin, D.; Zhao, Y. Innovations in the Development and Application of Edible Coatings for Fresh and Minimally Processed Fruits and Vegetables. Compr. Rev. Food Sci. Food Saf. 2007, 6, 60-75. [CrossRef]

37. King, A.H. Brown seaweed extracts (alginates). In Food Hydrocolloids; Glicksman, E., Ed.; CRC Press: Boca Raton, FL, USA, 1983; pp. 115-188.

38. Draget, K.I.; Smidsrod, O.; Skjak-Braek, G. Alginates from Algae. In Polysaccharides and Polyamides in the Food Industry. Properties, Production, and Patents; Steinbüchel, A., Rhee, S.K., Eds.; Wiley-Blackwell: Hoboken, NJ, USA, 2005; pp. 1-30.

39. Borchard, W.; Kenning, A.; Kapp, A.; Mayer, C. Phase diagram of the system sodium alginate/water: A model for biofilms. Int. J. Boil. Macromol. 2005, 35, 247-256. [CrossRef] [PubMed]

40. Dhanapal, A.; Sasikala, P.; Rajamani, L.; Kavitha, V.; Yazhini, G.; Banu, M.S. Edible films from polysaccharides. Food Sci. Qual. Manag. 2012, 3, 9-18.

41. Stabler, C.; Wilks, K.; Sambanis, A.; Constantinidis, I. The effects of alginate composition on encapsulated $\beta$ TC 3 cells. Biomaterials 2001, 22, 1301-1310. [CrossRef]

42. Klöck, G.; Pfeffermann, A.; Ryser, C.; Gröhn, P.; Kuttler, B.; Hahn, H.J.; Zimmermann, U.J.B. Biocompatibility of mannuronic acid-rich alginates. Biomaterials 1997, 18, 707-713. [CrossRef]

43. Draget, K.I.; Taylor, C. Chemical, physical and biological properties of alginates and their biomedical implications. Food Hydrocoll. 2011, 25, 251-256. [CrossRef]

44. Blanco-Pascual, N.; Montero, M.P.; Gómez-Guillén, M.C. Antioxidant film development from unrefined extracts of brown seaweeds Laminaria digitate and Ascophyllum nodosum. Food Hydrocoll. 2014, 37, 100-110. [CrossRef]

45. Haug, A.; Larsen, B. Quantitative determination of the uronic acid composition of alginates. Acta Chem. Scan. 1962, 16, 1908-1918. [CrossRef]

46. Grasdalen, H.; Larsen, B.; Smidsrød, O. A p.m.r. Study of the Composition and Sequence of Uronate Residues in Alginates. Carbohydr. Res. 1979, 68, 23-31. [CrossRef]

47. Penman, A.; Sanderson, G.R. A method for the determination of uronic acid sequence in alginates. Carbohydr. Res. 1972, 25, 273-282. [CrossRef]

48. Ji, M.; Wang, Y.; Xu, Z.; Guo, Y. Studies on the M:G ratios in alginate. Hydrobiologia 1984, 116/117, 554-556.

49. Kim, D.S. Uronic Acid Composition, Block Structure and Some Related Properties of Alginic Acid. Master's Thesis, Pusan Commercial (San Eup) University, Pusan, Korea, 1984.

50. Draget, K.I.; Skjak, G.; Smidsrød, O. Alginic acid gels: The effect of alginate chemical composition and molecular weight. Carbohydr. Polym. 1994, 25, 31-38. [CrossRef]

51. Kim, D.S.; Park, Y.H. Uronic acid composition, block structure and some related properties of alginic acid. On alginic acid prepared from Sargassum ringgoldianum. Korean J. Fish. Aquat. Sci. 1985, 18, 29-36. 
52. Laroche, C.; Michaud, P. A novel alginate from the brown seaweed Sargassum turbinaroides (Sargassae). In Current Topics on Bioprocesses in Food Industry; Larroche, C., Pandey, A., Dussap, C.G., Eds.; Asiatech Publisher, Inc.: New Delhi, India, 2009; Volume 2, pp. 71-92.

53. Davis, T.A.; Ramirez, M.; Mucci, A.; Larsen, B. Extraction, isolation and calcium binding of alginate from Sargassum spp. J. Appl. Physiol. 2004, 16, 275-284. [CrossRef]

54. Davis, T.A.; Llanes, F.; Volesky, B.; Mucci, A. Metal selectivity of Sargassum spp. and their alginates in relation to their a-L-guluronic acid content and conformation. Environ. Sci. Technol. 2003, 37, 261-267. [CrossRef] [PubMed]

55. Rosell, K.G.; Srivastava, L.M. Seasonal variation in the chemical constituents of the brown algae Macrocystis integrifolia and Nereocystis luetkeana. Can. J. Bot. 1984, 62, 2229-2236. [CrossRef]

56. Haug, A.; Larsen, B.; Smidsrød, O. Uronic acid sequence in alginate from different sources. Carbohydr. Res. 1974, 32, 217-225. [CrossRef]

57. Rhim, J.W. Physical and mechanical properties of water resistant sodium alginate films. LWT Food Sci. Technol. 2004, 37, 323-330. [CrossRef]

58. Kester, J.J.; Fennema, O.R. Edible films and coatings: A review. Food Technol. 1986, 40, 47-59.

59. Han, J.H. Edible Films and Coatings: A Review. In Innovations in Food Packaging, 2nd ed.; Han, J.H., Ed.; Academic Press; Elsevier: Amsterdam, The Netherlands, 2014; Chapter 9; pp. 213-255. [CrossRef]

60. Bonilla, J.; Atarés, L.; Vargas, M.; Chiralt, A. Edible films and coatings to prevent the detrimental effect of oxygen on food quality: Possibilities and limitations. J. Food Eng. 2012, 110, 208-213. [CrossRef]

61. Conca, K.R.; Yang, T.C.S. Edible food barrier coatings. In Biodegradable Polymers and Packaging; Ching, C., Kaplan, D., Thomas, D., Eds.; Technomic Publishing Co. Inc.: Lancaster, PA, USA, 1993; pp. 357-369.

62. Al-Tayyar, N.A.; Youssef, A.M.; Al-Hindi, R.R. Edible coatings and antimicrobial nanoemulsions for enhancing shelf life and reducing foodborne pathogens of fruits and vegetables: A review. Sustain. Mater. Technol. 2020, 26, e00215. [CrossRef]

63. McHugh, D.J. A guide to the seaweed industry. In FAO Fisheries Technical Paper 441; FAO: Rome, Italy, 2003.

64. Hassan, B.; Chatha, S.A.S.; Hussain, A.I.; Zia, K.M. Recent advances on polysaccharides, lipids and protein based edible films and coatings: A review. Int. J. Biol. Macromol. 2018, 109, 1095-1107. [CrossRef]

65. McHugh, D.J. Production and utilization of products from commercial seaweeds. In FAO Fisheries Technical Paper 288; FAO: Rome, Italy, 1987.

66. Osorio, F.A.; Molina, P.; Matiacevich, S.; Enrione, J.; Skurtys, O. Characteristics of hydroxy propyl methyl cellulose (HPMC) based edible film developed for blueberry coatings. Proc. Food Sci. 2011, 1, 287-293. [CrossRef]

67. Campos, C.A.; Gerschenson, L.N.; Flores, S.K. Development of edible films and coatings with antimicrobial activity. Food Bioproc. Tech. 2011, 4, 849-875. [CrossRef]

68. Cosenza, V.A.; Navarro, D.A.; Fissore, E.N.; Rojas, A.M.; Stortz, C.A. Chemical and rheological characterization of the carrageenans from Hypnea musciformis (Wulfen) Lamoroux. Carbohydr. Polym. 2014, 102, 780-789. [CrossRef]

69. Kapetanakou, A.E.; Manios, S.G.; Skandamis, P.N. Application of Edible Films and Coatings on Food. In Novel Food Preservation and Microbial Assessment Techniques; Boziaris, I.S., Ed.; CRC Press: Boca Raton, FL, USA; Taylor \& Francis: Abingdon, UK, 2014; pp. 237-273. [CrossRef]

70. Hambleton, A.; Perpinan-Saiz, N.; Fabra, M.J.; Voilley, A.; Debeaufort, F. The schroeder paradox or how the state of water affects the moisture transfer through edible films. Food Chem. 2012, 132, 1671-1678. [CrossRef]

71. De Araújo, I.W.F.; de Sousa Oliveira Vanderlei, E.; Rodrigues, J.A.G.; Coura, C.O.; Quinderé, A.L.G.; Fontes, B.P.; Queiroz, I.N.L.; Jorge, R.J.B.; Bezerra, M.M.; de Silva, A.A.R.; et al. Effects of a sulfated polysaccharide isolated from the red seaweed Solieria filiformis on models of nociception and inflammation. Carbohydr. Polym. 2011, 86, 1207-1215. [CrossRef]

72. Lopez-Pena, C.L.; McClements, D.J. Optimizing delivery systems for cationic biopolymers: Competitive interactions of cationic polylysine with anionic kappa-carrageenan and pectin. Food Chem. 2014, 153, 9-14. [CrossRef]

73. Schmidt, É.C.; Dos Santos, R.; Horta, P.A.; Maraschin, M.; Bouzon, Z.L. Effects of UVB radiation on the agarophyte Gracilaria domingensis (Rhodophyta, Gracilariales): Changes in cell organization, growth and photosynthetic performance. Micron 2010, 41, 919-930. [CrossRef]

74. Rhim, J.W. Effect of clay contents on mechanical and water vapor barrier properties of agar-based nanocomposite films. Carbohydr. Polym. 2011, 86, 691-699. [CrossRef]

75. Li, L.; Ni, R.; Shao, Y.; Mao, S. Carrageenan and its applications in drug delivery. Carbohydr. Polym. 2014, $103,1-11$. [CrossRef] [PubMed]

76. Motlagh, S.; Ravines, P.; Karamallah, K.A.; Ma, Q. The analysis of Acacia gums using electrophoresis. Food Hydrocol. 2006, 20, 848-854. [CrossRef]

77. Murmu, S.B.; Mishra, H.N. Optimization of the arabic gum based edible coating formulations with sodium caseinate and tulsi extract for guava. LWT Food Sci. Technol. 2017, 80, 271-279. [CrossRef]

78. Elmanan, M.; Al-Assaf, S.; Philips, G.O.; Williams, P.A. Studies of Acacia exudates gums: Part IV. Interfacial rheology of Acacia senegal and Acacia seyal. Food Hydrocol. 2008, 22, 682-689. [CrossRef]

79. Ali, A.; Maqbool, M.; Ramachandran, S.; Alderson, P.G. Gum arabic as a novel edible coating for enhancing shelf-life and improving postharvest quality of tomato (Solanum lycopersicum L.) fruit. Postharvest Biol. Technol. 2010, 58, 42-47. [CrossRef] 
80. Ali, A.; Maqbool, M.; Alderson, P.G.; Zahid, N. Effect of gum arabic as an edible coating on antioxidant capacity of tomato (Solanum lycopersicum L.) fruit during storage. Postharvest Biol. Technol. 2013, 76, 119-124. [CrossRef]

81. Antoniou, J.; Liu, F.; Majeed, H.; Qazi, H.J.; Zhong, F. Physicochemical and thermomechanical characterization of tara gum edible films: Effect of polyols as plasticizers. Carbohydr. Polym. 2014, 111, 359-365. [CrossRef]

82. Chen, Y.; Xu, L.; Wang, Y.; Chen, Z.; Zhang, M.; Chen, X. Characterization and functional properties of a pectin/tara gum based edible film with ellagitannins from the unripe fruits of Rubus chingii Hu. Food Chem. 2020, 325, 126964. [CrossRef]

83. Antoniou, J.; Liu, F.; Majeed, H.; Zhong, F. Characterization of tara gum edible films incorporated with bulk chitosan and chitosan nanoparticles: A comparative study. Food Hydrocol. 2015, 44, 309-319. [CrossRef]

84. Aydogdu, A.; Radkea, C.J.; Bezci, S.; Kirtil, E. Characterization of curcumin incorporated guar gum/orange oil antimicrobial emulsion films. Int. J. Biol. Macromol. 2020, 148, 110-120. [CrossRef]

85. Banegas, R.S.; Zornio, C.F.; Borges, A.M.G.; Porto, L.C.; Soldi, V. Preparation, Characterization and Properties of Films Obtained from Cross-linked Guar Gum. Polimeros 2013, 23, 182-188. [CrossRef]

86. Arismendi, C.; Chillo, S.; Conte, A.; Del Nobile, M.A.; Flores, S.; Gerschenson, L.N. Optimization of physical properties of xanthan gum/tapioca starch edible matrices containing potassium sorbate and evaluation of its antimicrobial effectiveness. LWT Food Sci. Technol. 2013, 53, 290-296. [CrossRef]

87. Ge, L.; Li, X.; Zhang, R.; Yang, R.; Ye, X.; Li, D.; Mu, D. Development and characterization of dialdehyde xanthan gum crosslinked gelatin based edible films incorporated with amino-functionalized montmorillonite. Food Hydrocol. 2015, 51, 129-135. [CrossRef]

88. Guo, J.M.; Ge, L.M.; Li, X.Y.; Mu, C.D.; Li, D.F. Periodate oxidation of xanthan gum and its crosslinking effects on gelatin-based edible films. Food Hydrocol. 2014, 39, 243-250. [CrossRef]

89. Gahruie, H.H.; Mostaghimi, M.; Ghiasi, F.; Tavakoli, S.; Naseri, M.; Hosseini, S.M.H. The effects of fatty acids chain length on the techno-functional properties of basil seed gum-based edible films. Inter. J. Biol. Macromol. 2020, 160, 245-251. [CrossRef]

90. Khazaei, N.; Esmaiili, M.; Djomeh, Z.E.; Ghasemlou, M.; Jouki, M. Characterization of new biodegradable edible film made from basil seed (Ocimum basilicum L.) gum. Carbohydr. Polym. 2014, 102, 199-206. [CrossRef]

91. Otoni, C.G.; Avena-Bustillos, R.J.; Azeredo, H.M.C.; Lorevice, M.V.; Moura, M.R.; Mattoso, L.H.C.; McHugh, T.H. Recent advances on edible films based on fruits and vegetables-A review. Compr. Rev. Food Sci. Food Saf. 2017, 16, 1151-1169. [CrossRef]

92. Dhall, R.K. Advances in Edible Coatings for Fresh Fruits and Vegetables: A Review. Crit. Rev. Food Sci. Nutr. 2013, 53, 435-450. [CrossRef]

93. Jahromi, M.; Niakousari, M.; Golmakani, M.T.; Mohammadifar, M.A. Physicochemical and structural characterization of sodium caseinate based film-forming solutions and edible films as affected by high methoxyl pectin. Int. J. Biol. Macromol. 2020, 165, 1949-1959. [CrossRef]

94. Coffin, D.R.; Fishman, M.L. Physical and mechanical properties of highly plasticized pectin/starch films. J. Appl. Polym. Sci. 1994, 54, 1311-1320. [CrossRef]

95. Bourtoom, T. Edible films and coatings: Characteristics and properties. Int. Food Res. J. 2008, 15, $237-248$.

96. Šuput, D.Z.; Lazić, V.L.; Popović, S.Z.; Hromiš, N.M. Edible films and coatings—Sources, properties and application. Food Feed Res. 2015, 42, 11-22. [CrossRef]

97. Kalkan, S.; Otağ, M.R.; Engin, M.S. Physicochemical and bioactive properties of edible methylcellulose films containing Rheum ribes L. extract. Food Chem. 2020, 307, 125524. [CrossRef]

98. Krochta, J.M.; Mulder-Johnson, C. Edible and biodegradable polymer films challenges and opportunities. Food Tech. 1997, 52, 661-674.

99. Li, H.; Shi, H.; He, Y.; Fei, X.; Peng, L. Preparation and characterization of carboxymethyl cellulose-based composite films reinforced by cellulose nanocrystals derived from pea hull waste for food packaging applications. Int. J. Biol. Macromol. 2020, 164, 4104-4112. [CrossRef] [PubMed]

100. Ebrahimi, B.; Mohammadi, R.; Rouhi, M.; Mortazavian, A.M.; Shojaee-Aliabadi, S.; Koushki, M.R. Survival of probiotic bacteria in carboxymethyl cellulose based edible film and assessment of quality parameters. LWT Food Sci. Technol. 2018, 87, 54-60. [CrossRef]

101. Zillo, R.R.; da Silva, P.P.M.; de Oliveira, J.; da Glória, E.M.; Spoto, M.H.F. Carboxymethylcellulose coating associated with essential oil can increase papaya shelf life. Sci. Hortic. 2018, 239, 70-77. [CrossRef]

102. Choi, W.S.; Singh, S.; Lee, Y.S. Characterization of edible film containing essential oils in hydroxypropyl methylcellulose and its effect on quality attributes of 'Formosa' plum (Prunus salicina L.). LWT Food Sci. Technol. 2016, 70, 213-222. [CrossRef]

103. Wani, A.A.; Singh, P.; Shah, M.A.; Schweiggert-Weisz, U.; Gul, K.; Wani, I.A. Rice starch diversity: Effects on structural, Morphological, Thermal, and Physicochemical Properties-A Review. Compr. Rev. Food Sci. Food Saf. 2012, 11, 417-436. [CrossRef]

104. Copeland, L.; Blazek, J.; Salman, H.; Tang, M.C. Form and functionality of starch. Food Hydrocoll. 2009, 23, 1527-1534. [CrossRef]

105. Tester, R.F.; Karkalas, J.; Qi, X. Starch—composition, fine structure and architecture. J. Cereal Sci. 2004, 39, 151-165. [CrossRef]

106. Guimarãesac, I.C.; Cristina dos Reis, K.; Galvão, E.; Menezes, E.G.T.; Rodrigues, A.C.; Ferreira da Silva, T.; Nolasco de Oliveira, I.R.; Vilas Boas, E.V.B. Cellulose microfibrillated suspension of carrots obtained by mechanical defibrillation and their application in edible starch films. Ind. Crop. Prod. 2016, 89, 285-294. [CrossRef]

107. Zhu, F. Modifications of starch by electric field based techniques. Trends Food Sci. Technol. 2018, 75, 158-169. [CrossRef]

108. Matignon, A.; Tecante, A. Starch retrogradation: From starch components to cereal products. Food Hydrocol. 2017, 68, 43-52. [CrossRef] 
109. Torres, F.G.; Troncoso, O.P.; Torres, C.; Diaz, D.A.; Amaya, E. Biodegradability and mechanical properties of starch films from Andean crops. Int. J. Biol. Macromol. 2011, 48, 603-606. [CrossRef] [PubMed]

110. Zavareze, E.R.; Pinto, V.Z.; Klein, B.; Halal, S.L.M.E.; Elias, M.C.; Prentice-Hernández, C.; Dias, A.R.G. Development of oxidised and heat-moisture treated potato starch film. Food Chem. 2012, 132, 344-350. [CrossRef] [PubMed]

111. Li, Y.; Shoemaker, C.F.; Ma, J.; Shen, X.; Zhong, F. Paste viscosity of rice starches of different amylose content and carboxymethylcellulose formed by dry heating and the physical properties of their films. Food Chem. 2008, 109, 616-623. [CrossRef]

112. Mali, S.; Grossmann, M.V.E.; Garcia, M.A.; Martino, M.N.; Zaritzky, N.E. Effects of controlled storage on thermal, mechanical and barrier properties of plasticized films from different starch sources. J. Food Eng. 2006, 75, 453-460. [CrossRef]

113. Thakur, R.; Pristijono, P.; Scarlett, C.J.; Bowyer, M.; Singh, S.P.; Vuong, Q.V. Starch-based films: Major factors affecting their properties. Int. J. Biol. Macromol. 2019, 132, 1079-1089. [CrossRef] [PubMed]

114. Januszewska-Jóźwiak, K.; Synowiecki, J. Characteristics and suitability of amaranth components in food biotechnology. Biotechnologia 2008, 3, 89-102.

115. Pietrzyk, S.; Fortuna, T. Impact of starch type and its oxidation conditions on retrogradation properties. Food Sci. Technol. Qual. 2005, 2, 23-32.

116. Shah, U.; Naqash, F.; Gani, A.; Masoodi, F.A. Art and Science behind Modified Starch Edible Films and Coatings: A Review. Compr. Rev. Food Sci. Food Saf. 2016, 15, 568-580. [CrossRef] [PubMed]

117. Rodríguez, M.; Osés, J.; Ziani, K.; Maté, J.I. Combined effect of plasticizers and surfactants on the physical properties of starch based edible films. Food Res. Int. 2006, 39, 840-846. [CrossRef]

118. Ryu, S.Y.; Rhim, J.W.; Roh, H.J.; Kim, S.S. Preparation and physical properties of zein-coated high amylose corn starch film. LWT Food Sci. Technol. 2002, 35, 680-686. [CrossRef]

119. de Moraes, J.O.; Scheibe, A.S.; Sereno, A.; Laurindo, J.B. Scale-up of the production of cassava starch based films using tape-casting. J. Food Eng. 2013, 119, 800-808. [CrossRef]

120. Wang, S.; Li, C.; Copeland, L.; Niu, Q.; Wang, S. Starch retrogradation: A comprehensive review. Compr. Rev. Food Sci. Food Saf. 2015, 14, 568-585. [CrossRef]

121. Ratnayake, W.S.; Jackson, D.S. Starch gelatinization. Adv. Food Nutr. Res. 2009, 55, 221-268. [CrossRef]

122. Shanks, R.; Kong, I. Thermoplastic Starch. In Thermoplastic Elastomers; El-Sonbati, A.Z., Ed.; InTechOpen: London, UK, 2012; Available online: https://www.intechopen.com/books/thermoplastic-elastomers/thermoplastic-starch (accessed on 11 February 2021). [CrossRef]

123. Ivanič, F.; Jochec-Mošková, D.; Janigová, I.; Chodák, I. Physical properties of starch plasticized by a mixture of plasticizers. Eur. Polym. J. 2017, 93, 843-849. [CrossRef]

124. Zhang, M.; Haga, A.; Sekiguchi, H.; Hirano, S. Structure of insect chitin isolated from beetle larva cuticle and silkworm (Bombyx mori) pupa exuvia. Int. J. Biol. Macromol. 2000, 27, 99-105. [CrossRef]

125. Majtan, J.; Bilikora, K.; Markowiec, O.; Grof, J.; Kogan, G.; Simuth, J. Isolation and characterization of chitin from bumblebee (Bombus terrestris). Int. J. Biol. Macromol. 2007, 40, 237-241. [CrossRef] [PubMed]

126. Sajomsang, W.; Gonil, P. Preparation and characterization of $\alpha$-chitin from cicada sloughs. Mater. Sci. Eng. C 2010, 30, 357-363. [CrossRef]

127. Elsabee, M.Z.; Abdou, E.S. Chitosan based edible films and coatings: A review. Mater. Sci. Eng. C 2013, 33, $1819-1841$. [CrossRef] [PubMed]

128. Tyliszczak, B.; Bialik-Wąs, K.; Drabczyk, A.; Kudłacik, S.; Sobczak-Kupiec, A. Animal-derived chitosans. Characteristics, comparison, application. Przem. Chem. 2016, 95, 2059-2062. [CrossRef]

129. Butola, B.S. Recent advances in chitosan polysaccharide and its derivatives in antimicrobial modification of textile materials. Int. J. Biol. Macromol. 2019, 121, 905-912. [CrossRef]

130. Domard, A.; Domard, M. Chitosan: Structure-properties relationship and biomedical applications. In Polymeric Biomaterials; Severian, D., Ed.; Marcel Decker Incorporated: New York, NY, USA, 2001; pp. 187-212. [CrossRef]

131. Youssef, A.M.; Abdel-Aziz, M.S.; El-Sayed, S.M. Chitosan nanocomposite films based on Ag-NP and Au-NP biosynthesis by Bacillus subtilis as packaging materials. Int. J. Biol. Macromol. 2014, 69, 185-191. [CrossRef]

132. Chaudhary, S.; Kumar, S.; Kumar, V.; Sharma, R. Chitosan nanoemulsions as advanced edible coatings for fruits and vegetables: Composition, fabrication and developments in last decade. Int. J. Biol. Macromol. 2020, 152, 154-170. [CrossRef]

133. Hajji, S.; Younes, I.; Affes, S.; Boufi, S.; Nasri, M. Optimization of the formulation of chitosan edible coatings supplemented with carotenoproteins and their use for extending strawberries postharvest life. Food Hydrocoll. 2018, 83, 375-392. [CrossRef]

134. Candir, E.; Ozdemir, A.E.; Aksoy, M.C. Effects of chitosan coating and modified atmosphere packaging on postharvest quality and bioactive compounds of pomegranate fruit cv. 'Hicaznar'. Sci. Hortic. 2018, 235, 235-243. [CrossRef]

135. Elsabee, M.Z. Chitosan-Based Edible Films. In Polysaccharides; Ramawat, K., Mérillon, J.M., Eds.; Springer: Cham, Switzerland, 2014; pp. 1-37. [CrossRef]

136. Kim, K.W.; Thomas, R.L.; Lee, C.; Park, H.J. Antimicrobial Activity of Native Chitosan, Degraded Chitosan, and OCarboxymethylated Chitosan. J. Food Prot. 2003, 66, 1495-1498. [CrossRef]

137. Tsai, G.; Su, W.; Chen, H.; Pan, C. Antimicrobial activity of shrimp chitin and chitosan from different treatments and applications of fish preservation. Fish. Sci. 2002, 68, 70-177. [CrossRef] 
138. Liu, H.; Du, Y.; Wang, X.; Sun, L. Chitosan kills bacteria through cell membrane damage. Int. J. Food Microbiol. 2004, 95, 147-155. [CrossRef]

139. Goy, R.C.; Morais, S.T.; Assis, O.B. Evaluation of the antimicrobial activity of chitosan and its quaternized derivative on E. coli and S. aureus growth. Rev. Bras. Farm. 2016, 26, 122-127. [CrossRef]

140. Singh, R.; Shitiz, K.; Singh, A. Chitin and chitosan: Biopolymers for wound management. Int. Wound J. 2017, 14, 1276-1289. [CrossRef] [PubMed]

141. Pavinatto, A.V.; de Almeida Mattos, A.C.G.; Malpass, M.H.; Okura, D.T.; Balogh, R.C.; Sanfelice, A. Coating with chitosan-based edible films for mechanical/biological protection of strawberries. Int. J. Biol. Macromol. 2020, 151, 1004-1011. [CrossRef] [PubMed]

142. Sharaf, O.M.; Al-Gamal, M.S.; Ibrahim, G.A.; Dabiza, N.M.; Salem, S.S.; El-Ssayad, M.F.; Youssef, A.M. Evaluation and characterization of some protective culture metabolites in free and nano-chitosan-loaded forms against common contaminants of Egyptian cheese. Carbohydr. Polym. 2019, 223, 115094. [CrossRef] [PubMed]

143. Bakshia, P.S.; Selvakumara, D.; Kadirvelub, K.; Kumara, N.S. Chitosan as an environment friendly biomaterial-A review on recent modifications and applications. Int. J. Biol. Macromol. 2019, 150, 1072-1083. [CrossRef]

144. Kaczmarek, M.B.; Struszczyk-Swita, K.; Li, X.; Szczęsna-Antczak, M.; Daroch, M. Enzymatic Modifications of Chitin, Chitosan, and Chitooligosaccharides. Front. Bioeng. Biotechnol. 2019, 7, 243. [CrossRef]

145. Tsigos, I.; Martinou, A.; Kafetzopoulos, D.; Bouriotis, V. Chitin deacetylases: New, versatile tools in biotechnology. Trends Biotechnol. 2000, 18, 305-312. [CrossRef] [PubMed]

146. Jaworska, M.M. Kinetics of enzymatic deacetylation of chitosan. Cellulose 2012, 19, 363-369. [CrossRef]

147. Kraśniewska, K.; Galus, S.; Gniewosz, M. Biopolymers-based materials containing silver nanoparticles as active packaging for food applications-A review. Int. J. Mol. Sci. 2020, 21, 698. [CrossRef]

148. Kim, S.J.; Ustunol, Z. Thermal properties, heat seal ability and seal attributes of whey protein isolate/lipid emulsion edible films. Food Eng. Phys. Prop. 2001, 66, 985-990. [CrossRef]

149. Sothornvit, R.; Rodsamran, P. Effect of a mango film on quality of whole and minimally processed mangoes. Postharvest Biol. Technol. 2008, 47, 407-415. [CrossRef]

150. Souza, B.W.S.; Cerqueira, M.A.; Martins, J.T.; Casariego, A.; Teixeira, J.A.; Vicente, A.A. Influence of electric fields on the structure of chitosan edible coatings. Food Hydrocoll. 2010, 24, 330-335. [CrossRef]

151. Gennadios, A.; Park, H.J.; Weller, C.L. Relative humidity and temperature effects on tensile strength of edible protein and cellulose ether films. Trans Asae 1993, 36, 1867-1872. [CrossRef]

152. Lourdin, D.; Valle, G.D. Influence of amylose content on starch films and foams. Carbohydr. Polym. 1995, 27, 261-270. [CrossRef]

153. Gottfrield, K.; Sztuka, K.; Statroszczyk, H.; Kołodziejska, I. Biodegradable, edible packaging materials of natural polymers for food. Packag. Mater. 2010, 8, 26-36.

154. Kim, S.R.B.; Choi, Y.-G.; Kim, J.-Y.; Lim, S.-T. Improvement of water solubility and humidity stability of tapioca starch film by incorporating various gums. LWT Food Sci. Technol. 2015, 64, 475-482. [CrossRef]

155. Maté, J.I.; Krochta, J.M. Oxygen uptake model for uncoated and coated peanuts. J. Food Eng. 1998, 35, 299-312. [CrossRef]

156. Hong, S.I.; Krochta, J.M. Oxygen barrier performance of whey-protein-coated plastic films as affected by temperature, relative humidity, base film and protein type. J. Food Eng. 2006, 77, 739-745. [CrossRef]

157. Sothornvit, R.; Pitak, N. Oxygen permeability and mechanical properties of banana films. Food Res. Int. 2007, 40, 365-370. [CrossRef]

158. Wang, X.; Sun, X.; Liu, H.; Li, M.; Ma, Z. Barrier and mechanical properties of carrot puree films. Food Bioprod. Process 2011, 89, 149-156. [CrossRef]

159. Ruelas-Chacon, X.; Contreras-Esquivel, J.C.; Montañez, J.; Aguilera-Carbo, A.F.; Reyes-Vega, M.L.; Peralta-Rodriguez, R.D.; Sanchéz-Brambila, G. Guar gum as an edible coating for enhancing shelf-life and improving postharvest quality of Roma tomato (Solanum lycopersicum L.). J. Food Qual. 2017, 8, 1-9. [CrossRef]

160. Valencia-Chamorro, S.A.; Palou, L.; del Río, M.Á.; Pérez-Gago, M.B. Performance of hydroxypropyl methylcellulose (HPMC)-lipid edible coatings with antifungal food additives during cold storage of 'Clemenules' mandarins. LWT Food Sci. Technol. 2011, 44, 2342-2348. [CrossRef]

161. Taşdelen, Ö.; Bayindirli, L. Controlled atmosphere storage and edible coating effects on storage life and quality of tomatoes. J. Food Process. Pres. 1998, 22, 303-320. [CrossRef]

162. Zapata, P.; Guillén, F.; Martínez-Romero, D.; Castillo, S.; Valero, D.; Serrano, M. Use of alginate or zein as edible coatings to delay postharvest ripening process and to maintain tomato (Solanum lycopersicon Mill) quality. J. Sci. Food Agric. 2008, 88, 1287-1293. [CrossRef]

163. Navarro-Tarazaga, M.L.L.; Del Río, M.A.; Krochta, J.M.; Pérez-Gago, M.B. Fatty acid effect on hydroxypropyl methylcellulosebeeswax edible film properties and postharvest quality of coated 'ortanique' mandarins. J. Agric. Food Chem. 2008, 56, 10689-10696. [CrossRef]

164. Daudt, R.M.; Avena-Bustillos, R.J.; Williams, T.; Wood, D.F.; Külkamp-Guerreiro, I.C.; Marczak, L.D.F.; McHugh, T.H. Comparative study on properties of edible films based on pinhão (Araucaria angustifolia) starch and flour. Food Hydrocoll. 2016, 60, 279-287. [CrossRef]

165. Galindez, A.; Daza, L.D.; Homez-Jara, A.; Eim, V.S.; Váquiro, H.A. Characterization of ulluco starch and its potential for use in edible films prepared at low drying temperature. Carbohydr. Polym. 2019, 215, 143-150. [CrossRef] 
166. Ochoa-Yepes, O.; Medina-Jaramillo, C.; Guz, L.; Famá, L. Biodegradable and edible starch composites with fiber-rich lentil flour to use as food packaging. Starch 2018, 70, 1700222. [CrossRef]

167. Bonilla, J.; Atarés, L.; Vargas, W.; Chiralt, A. Properties of wheat starch film-forming dispersions and films as affected by chitosan addition. J. Food Eng. 2013, 114, 303-312. [CrossRef]

168. Vargas, M.; Pastor, C.; Chiralt, A.; McClements, D.J.; Gonzalez-Martinez, C. Recent advances in edible coatings for fresh and minimally processed fruits. Crit. Rev. Food Sci. Nutr. 2008, 48, 496-511. [CrossRef] [PubMed]

169. Gutierrez, T.J.; Tapia, M.S.; Perez, E.; Fama, L. Structural and mechanical properties of edible films made from native and modified cush-cush yam and cassava starch. Food Hydrocoll. 2015, 45, 211-217. [CrossRef]

170. Kurek, M.; Galus, S.; Debeaufort, F. Surface, mechanical and barrier properties of bio-based composite films based on chitosan and whey protein. Food Packag. Shelf Life 2014, 1, 56-67. [CrossRef]

171. Park, S.Y.; Lee, B.I.; Jung, S.T.; Park, H.J. Biopolymer composite films based on k-carrageenan and chitosan. Mater. Res. Bull. 2001, 36, 511-519. [CrossRef]

172. Suyatma, N.E.; Copinet, A.; Tighzert, L.; Coma, V. Mechanical and barrier properties of biodegradable films made from chitosan and poly (lactic acid) blends. J. Polym. Environ. 2004, 12, 1-6. [CrossRef]

173. Robles-Flores, G.; Abud-Arcgilla, M.; Ventura-Canseco, L.M.C.; Meza-Gordillo, R.; Grajales-Lagunes, A.; Ruiz-Cabrera, M.A.; Gutiérrez-Miceli, F.A. Development and evaluation of a film and edible coating obtained from the Cajanus cajan seed applied to fresh strawberry fruit. Food Bioproc. Technol. 2018, 11, 2172-2181. [CrossRef]

174. Nouraddini, M.; Esmaiili, M.; Mohtarami, F. Development and characterization of edible films based on eggplant flour and corn starch. Int. J. Biol. Macromol. 2018, 120, 1639-1645. [CrossRef]

175. Pinotti, A.; Garcia, M.A.; Martino, M.N.; Zaritzky, N.E. Study on microstructure and physical properties of composite films based on chitosan and methylcellulose. Food Hydrocoll. 2007, 21, 66-72. [CrossRef]

176. Faber, J.N.; Harris, L.J.; Parish, M.E.; Beuchat, L.R.; Suslow, T.V.; Gorney, J.R.; Garrett, E.H.; Busta, F.F. Microbiological safety of controlled and modified atmosphere packaging of fresh and fresh-cut produce. Compr. Rev. Food Sci. Food Saf. 2003, 2, 142-160. [CrossRef]

177. Chakravartula, S.S.N.; Soccio, M.; Lotti, N.; Balestra, F.; Rosa, M.D.; Siracusa, V. Characterization of Composite Edible Films Based on Pectin/Alginate/Whey Protein Concentrate. Materials 2019, 12, 2454. [CrossRef] [PubMed]

178. Galus, S.; Uchański, P.; Lenart, A. Colour, mechanical properties and water vapour permeability of pectin films. Acta Agrophys. 2013, 20, 375-384.

179. Galus, S.; Lenart, A. Development and characterization of composite edible films based on sodium alginate and pectin. J. Food Eng. 2013, 115, 459-465. [CrossRef]

180. Pérez-Gago, M.B.; González-Aguilar, G.A.; Olivas, G.I. Edible coatings for fruits and vegetables. Stewart Postharv. Rev. 2010, 6, 1-14. [CrossRef]

181. Vieira, M.G.A.; da Silva, M.A.; dos Santos, L.O.; Beppu, M.M. Natural-based plasticizers and biopolymer films: A review. Eur. Polym. J. 2011, 47, 254-263. [CrossRef]

182. Jouki, M.; Khazaei, N.; Ghasemlou, M.; HadiNezhad, M. Effect of glycerol concentration on edible film production from cress seed carbohydrate gum. Carbohydr. Polym. 2013, 96, 39-46. [CrossRef] [PubMed]

183. Ibrahim, M.I.J.; Sapuan, S.M.; Zainudin, E.S.; Zuhri, M.Y.M. Physical, thermal, morphological, and tensile properties of cornstarchbased films as affected by different plasticizers. Int. J. Food Prop. 2019, 22, 925-941. [CrossRef]

184. Xu, J.; Xia, R.; Zheng, L.; Yuan, T.; Sun, R. Plasticized hemicelluloses/chitosan-based edible films reinforced by cellulose nanofiber with enhanced mechanical properties. Carbohydr. Polym. 2019, 224, 115164. [CrossRef] [PubMed]

185. Mantzari, G.; Raphaelides, N.S.; Exarhopoulos, S. Effect of sorbitol addition on the physicochemical characteristics of starch-fatty acid systems. Carbohydr. Polym. 2010, 79, 154-163. [CrossRef]

186. Morillon, V.; Debeaufort, F.; Blond, G.; Capelle, M.; Voilley, A. Factors affecting the moisture permeability of lipid-based edible films: A review. Crit. Rev. Food Sci. 2002, 42, 67-89. [CrossRef]

187. Rhim, J.W. Increase in water vapor barrier property of biopolymer-based edible films and coatings by compositing with lipid materials. Food Sci. Biotechnol. 2004, 13, 528-535.

188. Xu, Y.; Ren, X.; Hanna, M.A. Chitosan/clay nanocomposite film preparation and characterization. J. Appl. Polym. Sci. 2006, 99, 1684-1691. [CrossRef]

189. Muscat, D.; Adhikari, B.; Chaudhary, D.S. Comparative study on film forming behavior of low and high amylose starches using glycerol and xylitol as plasticizers. J. Food Eng. 2012, 109, 189-201. [CrossRef]

190. Edhirej, A.; Sapuan, S.M.; Jawaid, M.; Zahari, N.I. Effect of Various Plasticizers and Concentration on the Physical, Thermal, Mechanical, and Structural Properties of Cassava-Starch-Based Films. Starch-Stärke 2017, 69, 1500366. [CrossRef]

191. Smits, A.L.M.; Kruiskamp, P.H.; van Soest, J.J.G.; Vliegenthart, J.F.G. The influence of various small plasticisers and maltooligosaccharides on the retrogradation of (partly) gelatinised starch. Carbohydr. Polym. 2003, 51, 417-424. [CrossRef]

192. Jiménez, A.; Fabra, M.J.; Talens, P.; Chiralt, A. Effect of re-crystallization on tensile, optical and water vapour barrier properties of corn starch films containing fatty acids. Food Hydrocoll. 2012, 26, 302-310. [CrossRef]

193. Talja, R.A.; Helén, H.; Roos, Y.H.; Jouppila, K. Effect of type and content of binary polyol mixtures on physical and mechanical properties of starch-based edible films. Carbohydr. Polym. 2008, 71, 269-276. [CrossRef] 
194. Talja, R.A.; Helén, H.; Roos, Y.H.; Jouppila, K. Effect of various and polyol contents on physical and mechanical properties of potato starch-based films. Carbohydr. Polym. 2007, 67, 288-295. [CrossRef]

195. Parra, D.F.; Tadini, C.C.; Ponce, P.; Lugao, A.B. Mechanical properties and water vapor transmission in some blends of cassava starch edible films. Carbohydr. Polym. 2004, 58, 475-481. [CrossRef]

196. Balaguer, M.P.; Gómez-Estaca, J.; Gavara, R.; Hernandez-Munoz, P. Functional properties of bioplastics made from wheat gliadins modified with cinnamaldehyde. J. Agric. Food Chem. 2011, 59, 6689-6695. [CrossRef]

197. Azeredo, H.M.; Waldron, K.W. Crosslinking in polysaccharide and protein films and coatings for food contact-A review. Trends Food Sci. Technol. 2016, 52, 109-122. [CrossRef]

198. Wittaya, T. Protein-based edible films: Characteristics and improvement of properties. In Structure and Function of Food Engineering; Eissa, A.A., Ed.; IntechOpen: London, UK, 2012; pp. 43-70. Available online: https://www.intechopen.com/books/structureand-function-of-food-engineering/protein-based-edible-films-characteristics-and-improvement-of-properties (accessed on 11 February 2021). [CrossRef]

199. Zink, J.; Wyrobnik, T.; Prinz, T.; Schmid, M. Physical, chemical and biochemical modifications of protein-based films and coatings: An extensive review. Int. J. Mol. Sci. 2016, 17, 1376. [CrossRef] [PubMed]

200. Wu, H.; Lei, Y.; Lu, J.; Zhu, R.; Xiao, D.; Jiao, C.; Xia, R.; Zhang, Z.; Shen, G.; Liu, Y.; et al. Effect of citric acid induced crosslinking on the structure and properties of potato starch/chitosan composite films. Food Hydrocoll. 2019, 97, 105208. [CrossRef]

201. Li, K.; Zhu, J.; Guan, G.; Wu, H. Preparation of chitosan-sodiumalginate films through layer-by-layer assembly and ferulic acid crosslinking: Film properties, characterization, and formation mechanism. Int. J. Biol. Macromol. 2019, 122, 485-492. [CrossRef] [PubMed]

202. Wang, H.; Liao, Y.; Wu, A.; Li, B.; Qian, J.; Ding, F. Effect of sodium trimetaphosphate on chitosan-methylcellulose composite films: Physicochemical properties and food packaging application. Polymers 2019, 11, 368. [CrossRef]

203. Parreidt, T.S.; Schott, M.; Schmid, M.; Müller, K. Effect of presence and concentration of plasticizers, vegetable oils, and surfactants on the properties of sodium-alginate based edible coatings. Int. J. Mol. Sci. 2018, 19, 742. [CrossRef]

204. Ziani, K.; Oses, J.; Coma, V.; Maté, J.I. Effect of the presence of glycerol and Tween 20 on the chemical and physical properties of films based on chitosan with different degree of deacetylation. LWT Food Sci. Technol. 2008, 41, 2159-2165. [CrossRef]

205. Sapper, M.; Bonet, M.; Chiralt, A. Wettability of starch-gellan coatings on fruits, as affected by the incorporation of essential oil and/or surfactants. LWT Food Sci. Technol. 2019, 116, 108574. [CrossRef]

206. Sedlaříková, J.; Janalíková, M.; Rudolf, O.; Pavlačková, J.; Egner, P.; Peer, P.; Varad'ová, V.; Krejčí, J. Chitosan/thyme oil systems as affected by stabilizing agent: Physical and antimicrobial properties. Coatings 2019, 9, 165. [CrossRef]

207. Pérez-Gago, M.B.; Rhim, J.W. Edible coating and film materials: Lipid bilayers and lipid emulsions. In Innovations in Food Packaging, 2nd ed.; Elsevier: London, UK, 2014; pp. 325-350. [CrossRef]

208. Pérez-Gago, M.B.; Krochta, J.M. Emulsion and bi-layer edible films. In Innovations in Food Packaging, 1st ed.; Elsevier: Amsterdam, The Netherlands, 2005; pp. 384-402. [CrossRef]

209. Baldwin, E.A.; Nisperos-Carriedo, M.O.; Hagenmaier, R.D.; Baker, R.A. Use of lipids in coatings for food products. Food Technol. 1997, 51, 56-62.

210. Vargas, M.; Albors, A.; Chiralt, A.; Gonzalez-Martınez, C. Characterization of chitosan-oleic acid composite films. Food Hydrocoll. 2009, 23, 536-547. [CrossRef]

211. Park, S.Y.; Marsh, K.S.; Rhim, J.W. Characteristics of Different Molecular Weight Chitosan Films Affected by the Type of Organic Solvents. J. Food Sci. 2002, 67, 194-197. [CrossRef]

212. Xu, Y.X.; Kim, K.M.; Hanna, M.A.; Nag, D. Chitosan-starch composite film: Preparation and characterization. Ind. Crop. Prod. 2005, 21, 185-192. [CrossRef]

213. Haider, S.; Park, S.-Y.; Lee, S.-H. Preparation, swelling and electro-mechano-chemical behaviors of a gelatin-chitosan blend membrane. Soft Matter 2008, 4, 485-492. [CrossRef]

214. Silva, S.S.; Goodfellow, B.J.; Benesch, J.; Rocha, J.; Mano, J.F.; Reis, R.L. Morphology and miscibility of chitosan/soy protein blended membranes. Carbohydr. Polym. 2007, 70, 25-31. [CrossRef]

215. Pereda, M.; Aranguren, M.I.; Marcovich, N.E. Characterization of chitosan/caseinate films. J. Appl. Polym. Sci. 2008, 107, 1080-1090. [CrossRef]

216. Souza, B.W.S.; Cerqueira, M.A.; Casariego, A.; Lima, A.M.P.; Teixeira, J.A.; Vicente, A.A. Effect of moderate electric fields in the permeation properties of chitosan coatings. Food Hydrocoll. 2009, 23, 2110-2115. [CrossRef]

217. Souza, B.W.S.; Cerqueira, M.A.; Teixeira, J.A.; Vicente, A.A. The Use of Electric Fields for Edible Coatings and Films Development and Production: A Review. Food Eng. Rev. 2010, 2, 244-255. [CrossRef]

218. Lei, L.; Zhi, H.; Zhang, X.; Takasuke, I.; Zaigui, L. Effects of different heating methods on the production of protein lipid film. J. Food Eng. 2007, 82, 292-297. [CrossRef]

219. Pereira, R.N.; Souza, B.W.S.; Cerqueira, M.A.; Teixeira, J.A.; Vicente, A.A. Effect of electric fields on protein unfolding and aggregation: Influence on edible films formation. Biomacromolecules 2010, 11, 2912-2918. [CrossRef]

220. Garcia, M.A.; Pinotti, A.; Martino, M.; Zaritzky, N. Electrically treated composite films based on chitosan and methylcellulose blends. Food Hydrocoll. 2009, 23, 722-728. [CrossRef]

221. Balau, L.; Lisa, G.; Popa, M.I.; Tura, V.; Melnig, V. Physico-chemical properties of chitosan films. Cent. Eur. J. Chem. 2004, 2, 638-647. [CrossRef] 
222. Miller, K.; Krochta, J. Oxygen and aroma barrier properties of edible films: A review. Trends Food Sci. Technol. 1997, 8 , 228-237. [CrossRef]

223. De Pena, M.; Welti-Chanes, J.; Martin-Belloso, O. Novel technologies to improve food safety and quality. Curr. Opin. Food Sci. 2019, 30, 1-7. [CrossRef]

224. Ayranci, E.; Tunc, S.A. A method for the measurement of the oxygen permeability and the development of edible films to reduce the rate of oxidative reactions in fresh foods. Food Chem. 2003, 80, 423-431. [CrossRef]

225. Jiang, T.; Feng, L.; Wang, Y. Effect of alginate/nano-Ag coating on microbial and physicochemical characteristics of shiitake mushroom (Lentinus edodes) during cold storage. Food Chem. 2013, 141, 954-960. [CrossRef]

226. Sipahi, R.E.; Castell-Perez, M.E.; Moreira, R.G.; Gomes, C.; Castillo, A. Improved multilayered antimicrobial alginate-based edible coating extends the shelf life of fresh-cut watermelon (Citrullus lanatus). LWT Food Sci. Technol. 2013, 51, 9-15. [CrossRef]

227. Robles-Sánchez, R.M.; Rojas-Graü, M.A.; Odriozola-Serrano, I.; González-Aguilar, G.; Martin-Belloso, O. Influence of alginatebased edible coating as carrier of antibrowning agents on bioactive compounds and antioxidant activity in fresh-cut Kent mangoes. LWT Food Sci. Technol. 2013, 50, 240-246. [CrossRef]

228. Medina-Jaramillo, C.; Quintero-Pimiento, C.; Gómez-Hoyos, C.; Zuluaga-Gallego, R.; López-Córdoba, A. Alginate-Edible Coatings for Application on Wild Andean Blueberries (Vaccinium meridionale Swartz):Effect of the Addition of Nanofibrils Isolated from Cocoa By-Products. Polymers 2020, 12, 824. [CrossRef] [PubMed]

229. De Jesús Salas-Méndez, E.; Vicente, A.; Pinheiro, A.C.; Ballesteros, L.F.; Silva, P.; Rodríguez-García, R.; Peña-Ramos, F.M Application of edible nanolaminate coatings with antimicrobial extract of Flourensia cernua to extend the shelf-life of tomato (Solanum lycopersicum L.) fruit. Postharvest Biol. Technol. 2019, 150, 19-27. [CrossRef]

230. Poverenov, E.; Danino, S.; Horev, B.; Granit, R.; Vinokur, Y.; Rodov, V. Layer-by-layer electrostatic deposition of edible coating on fresh cut melon model: Anticipated and unexpected effects of alginate-chitosan combination. Food Bioprocess Technol. 2014, 7, 1424-1432. [CrossRef]

231. Li, X.Y.; Du, X.L.; Liu, Y.; Tong, L.J.; Wang, Q.; Li, J.L. Rhubarb extract incorporated into an alginate-based edible coating for peach preservation. Sci. Hortic. 2019, 257, 108685. [CrossRef]

232. Hamzah, H.M.; Osman, A.; Tan, C.P.; Mohamad Ghazali, F. Carrageenan as an alternative coating for papaya (Carica papaya L. cv. Eksotika). Postharvest Biol. Technol. 2013, 75, 142-146. [CrossRef]

233. Lee, J.Y.; Park, H.J.; Lee, C.Y.; Choi, W.Y. Extending shelf-life of minimally processed apples with edible coatings and anti-browning agents. LWT Food Sci. Technol. 2003, 36, 323-329. [CrossRef]

234. Rhim, J.W.; Wang, L.F. Mechanical and water barrier properties of agar/kappa-carrageenan/konjac glucomannan ternary blend biohydrogel films. Carbohydrat. Polym. 2013, 96, 71-81. [CrossRef]

235. Geraldine, R.M.; Ferreira, N.; Alvarenga, B.; Almeida, G. Characterization and effect of edible coatings on minimally processed garlic quality. Carbohydr. Polym. 2008, 72, 403-409. [CrossRef]

236. Kyu Kyu, W.N.; Jitareerat, P.; Kanlayanarat, S.; Sangchote, S. Effects of cinnamon extract, chitosan coating, hot water treatment and their combinations on crown rot disease and quality of banana fruit. Postharvest Biol. Technol. 2007, 45, 333-340. [CrossRef]

237. Martínez-Camacho, A.P.; Cortez-Rocha, M.O.; Ezquerra-Brauer, J.M.; Graciano-Verdugo, A.Z.; Rodriguez-Félix, F.; Castillo-Ortega, M.M.; Yépiz-Gómez, M.S.; Plascencia-Jatomea, M. Chitosan composite films: Thermal, structural, mechanical an antifungal properties. Carbohydr. Polym. 2010, 82, 305-315. [CrossRef]

238. Li, H.; Yu, T. Effect of chitosan on incidence of brown rot, quality and physiological attributes of postharvest peach fruit. J. Sci. Food Agric. 2000, 81, 269-274. [CrossRef]

239. Chen, C.; Nie, Z.; Wan, C.; Chen, J. Preservation of Xinyu Tangerines with an Edible Coating Using Ficus hirta Vahl. Fruits Extract-Incorporated Chitosan. Biomolecules 2019, 9, 46. [CrossRef] [PubMed]

240. Azimzadeh, B.; Jahadi, M. Effect of chitosan edible coating with Laurus nobilis extract on shelf life of cashew. Food Sci. Nutr. 2018, 6, 871-877. [CrossRef] [PubMed]

241. Velickova, E.; Winkelhausen, E.; Kuzmanova, S.; Alves, V.D.; Moldao-Martins, M. Impact of chitosan-beeswax edible coatings on the quality of fresh strawberries (Fragaria ananassa cv Camarosa) under commercial storage conditions. LWT Food Sci. Technol. 2013, 52, 80-92. [CrossRef]

242. Jiao, W.; Shu, C.; Li, X.; Cao, J.; Fan, X.; Jiang, W. Preparation of a chitosan-chlorogenic acid conjugate and its application as edible coating in postharvest preservation of peach fruit. Postharvest Biol. Technol. 2019, 154, 129-136. [CrossRef]

243. Escamilla-García, M.; Rodríguez-Hernández, M.J.; Hernández-Hernández, H.M.; Delgado-Sánchez, L.F.; García-Almendárez, B.E.; Amaro-Reyes, A.; Regalado-González, C. Effect of an Edible Coating Based on Chitosan and Oxidized Starch on Shelf Life of Carica papaya L., and Its Physicochemical and Antimicrobial Properties. Coatings 2018, 8, 318. [CrossRef]

244. Maqbool, M.; Ali, A.; Ramachandran, S.; Smith, D.R.; Alderson, P.G. Control of postharvest anthracnose of banana using a new edible composite coating. Crop Prot. 2010, 29, 1136-1141. [CrossRef]

245. Tesfay, S.Z.; Magwaza, L.S. Evaluating the efficacy of moringa leaf extract, chitosan and carboxymethyl cellulose as edible coatings for enhancing quality and extending postharvest life of avocado (Persea americana Mill.) fruit. Food Packag. Shelf Life 2017, 11, 40-48. [CrossRef]

246. Botrel, D.A.; Soares, N.F.F.; Geraldine, R.M.; Pereira, R.M.; Fontes, E.A.F. Quality of minimally processed garlic (Allium sativum) coated with antimicrobial edible coating. Ciênc. Tecnol. Aliment. Camp. 2007, 27, 32-38. [CrossRef] 
247. Thakur, R.; Pristijono, P.; Golding, J.B.; Stathopoulos, C.E.; Scarlett, C.; Bowyer, M.; Singh, S.P.; Vuong, Q.V. Effect of starch physiology, gelatinization, and retrogradation on the attributes of rice starch-t-carrageenan film. Starch-Stärke 2018, 70, 1700099. [CrossRef]

248. Adetunji, C.O.; Fawole, O.B.; Arowora, K.A.; Nwaubani, S.I.; Oloke, J.K.; Adepoju, A.O.; Adetunji, J.B.; Ajani, A.O. Performance of Edible Coatings from Carboxymethylcellulose(CMC) and Corn Starch(CS) Incorporated with Moringa Oleifera Extract on Citrus Sinensis Stored at Ambient Temperature. Agrosearch 2013, 13, 77-85. [CrossRef]

249. Tesfay, S.Z.; Magwaza, L.S.; Mditshwa, A.; Mbili, N. Carboxyl methylcellulose (CMC) incorporated with moringa leaf and seed extracts as new postharvest organic edible coating for avocado (Persea americana Mill.) fruit. Acta Hortic. 2018, 1201, 161-168. [CrossRef]

250. Ebrahimi, F.; Rastegar, S. Preservation of mango fruit with guar-based edible coatings enriched with Spirulina platensis and Aloe vera extract during storage at ambient temperature. Sci. Hortic. 2020, 265, 109258. [CrossRef]

251. Kubheka, S.F.; Tesfay, Z.S.; Mditshwa, A.; Magwaza, L.S. Evaluating the Efficacy of Edible Coatings Incorporated with Moringa Leaf Extract on Postharvest of 'Maluma' Avocado Fruit Quality and Its Biofungicidal Effect. Hort. Sci. 2020, 55, 1-6. [CrossRef]

252. Bnuyan, I.; Hindi, N.K.K.; Jebur, M.H.; Mahdi, M.A. In vitro antimicrobial activity of gum arabic (Al Manna and Tayebat) prebiotics against infectious pathogens. Int. J. Pharm. Pharmac. Res. 2015, 3, 77-85.

253. El-Anany, A.M.; Hassan, G.F.A.; Ali, F.M.R. Effects of edible coatings on the shelf-life and quality of Anna apple (Malus domestica Borkh) during cold storage. J. Food Technol. 2009, 7, 5-11.

254. Tahir, H.E.; Xiaobo, Z.; Jiyong, S.; Mahunu, G.K.; Zhai, X.; Mariod, A.A. Quality and postharvest-shelf life of cold-stored strawberry fruit as affected by gum arabic (Acacia senegal) edible coating. J. Food Biochem. 2018, 42, e12527. [CrossRef]

255. Rojas-Graü, M.A.; Tapia, M.S.; Rodríguez, F.J.; Carmona, A.J.; Martin-Belloso, O. Alginate and gellan-based edible coatings as carriers of antibrowning agents applied on fresh-cut Fuji apples. Food Hydrocoll. 2007, 21, 118-127. [CrossRef]

256. Salehi, F. Edible Coating of Fruits and Vegetables Using Natural Gums: A Review. Int. J. Fruit Sci. 2020, 20, S570-S589. [CrossRef]

257. Amanatidou, A.; Slump, R.A.; Gorris, L.G.M.; Smid, E.J. High oxygen and high carbon dioxide modified atmospheres for shelf-life extension of minimally processed carrots. J. Food Sci. 2000, 65, 61-66. [CrossRef]

258. Valero, D.; Díaz-Mula, H.M.; Zapata, P.J.; Guillén, F.; Martínez-Romero, D.; Castillo, S.; Serrano, M. Effects of alginate edible coating on preserving fruit quality in four plum cultivars during postharvest storage. Postharvest Biol. Technol. 2013, 77, 1-6. [CrossRef]

259. Appelqvist, I.A.; Debet, R.M.M. Starch-biopolymer interactions-A review. Food Rev. Int. 1997, 13, 163-224. [CrossRef]

260. Saberi, B.; Golding, J.B.; Chockchaisawasdee, S.; Scarlett, C.J.; Stathopoulos, C.E. Effect of biocomposite edible coatings based on pea starch and guar gum on nutritional quality of "Valencia" orange during storage. Starch 2018, 70, 1700299. [CrossRef]

261. Pizato, S.; Cortez-Vega, W.R.; Souza, J.T.A.; Prentice-Hernández, C.; Borges, C.D. Effects of different edible coatings in physical, chemical and microbiological characteristics of minimally processed peaches (Prunus persica L. batsch). J. Food Saf. 2013, 33, 30-39. [CrossRef]

262. Maqbool, M.; Ali, A.; Alderson, P.G.; Mohamed, M.T.M.; Siddiqui, Y.; Zahis, N. Postharvest application of gum arabic and essential oils for controlling anthracnose and quality of banana and papaya during cold storage. Postharvest Biol. Technol. 2011, 62, 71-76. [CrossRef]

263. Tahir, H.E.; Xiaobo, Z.; Mahunu, G.K.; Arslan, M.; Abdalhai, M.; Zhihua, L. Recent developments in gum edible coatings applications for fruits and vegetables preservation: A review. Carbohydr. Polym. 2019, 224, 115141. [CrossRef] [PubMed]

264. Rangel-Marrón, M.; Mani-López, E.; Palou, E.; López-Malo, A. Effects of alginate-glycerol-citric acid concentrations on selected physical, mechanical, and barrier properties of papaya puree-based edible films and coatings, as evaluated by response surface methodology. LWT Food Sci. Technol. 2019, 101, 83-91. [CrossRef]

265. Andrade, R.M.S.; Ferreira, S.L.; Gonçalves, É.B.A. Development and characterization of edible films based on fruit and vegetable residues. J. Food Sci. 2016, 81, E412-E418. [CrossRef] [PubMed]

266. Mariniello, L.; Giosafatto, C.V.; Di, P.P.; Sorrentino, A.; Porta, R.J. Swelling, mechanical, and barrier properties of albedobased films prepared in the presence of phaseolin cross-linked or not by transglutaminase. Biomacromolecules 2010, 11, 2394-2398. [CrossRef]

267. We, H.; Lei, Y.; Zhu, R.; Zhao, M.; Lu, J.; Xiao, D.; Jiao, C.; Zhang, Z.; Shen, G.; Li, S. Preparation and characterization of bioactive edible packaging films based on pomelo peel flours incorporating tea polyphenol. Food Hydrocoll. 2019, 90, 41-49. [CrossRef]

268. Riaz, S.; Sultan, M.T.; Sibt-e-Abass, M.; Irman, M.; Ahmad, R.S.; Hussain, M.B.; Shariati, M.A.; Kosenko, I.S.; Kleymenova, N.L.; Egorova, G.N. Extraction of polysaccharides from opuntia cactus for its potential application in edible coating to improve the shelf life of citrus (Kinnow mandarin) fruit. J. Microbiol. Biotechnol. Food Sci. 2018, 8, 745-750. [CrossRef]

269. Douglas, M.; Heys, J.; Smallfield, B. Herb Spice and Essential Oil: Post-Harvest Operation in Developing Country, 2nd ed.; UNIDO and FAO: Vienna, Austria, 2005; pp. 45-55.

270. Yahaya, W.A.W.; Abu Yazid, N.; Azman, N.A.M.; Almajano, M.P. Antioxidant Activities and Total Phenolic Content of Malaysian Herbs as Components of Active Packaging Film in Beef Patties. Antioxidants 2019, 8, 204. [CrossRef]

271. Shivpuri, A.; Sharma, O.P.; Jhamaria, S.L. Fungitoxic properties of plant extracts against pathogenic fungi. J. Mycol. Plant Pathol. 1997, 70, 13-17.

272. Ayala-Zavala, J.F.; Oms-Oliu, G.; Odriozola-Serrano, I.; Gonzalez-Aguilar, G.A.; Alvarez-Parrilla, E.; Martin-Belloso, O. Biopreservation of fresh-cut tomatoes using natural antimicrobials. Eur. Food Res. Technol. 2008, 226, 1047-1055. [CrossRef] 
273. Du Plooy, W.; Regnier, T.; Combrinck, S. Essential oil amended coatings as alternatives to synthetic fungicides in citrus postharvest management. Postharvest Biol. Technol. 2009, 53, 117-122. [CrossRef]

274. Dorman, H.J.; Deans, S.G. Antimicrobial agents from plants: Antibacterial activity of plant volatile oils. J. Appl. Microbiol. 2000, 88, 308-316. [CrossRef] [PubMed]

275. Marino, M.; Bersani, C.; Comi, G. Impedance measurements to study the antimicrobial activity of essential oils from Lamiacea and compositae. Int. J. Food Microbiol. 2001, 76, 187-195. [CrossRef]

276. Chauhan, S.; Gupta, K.C.; Agrawal, M. Application of biodegradable Aloe vera gel to control postharvest decay and longer the shelf life of Grapes. Int. Curr. Microbiol. Appl. Sci. 2014, 3, 632-642.

277. Nasution, Z.; Wei, J.N.; Hamzah, Y. Characteristics of fresh cut Guava coated with Aloe vera gel as affected by different additives. Witthayasan Kasetsat 2015, 49, 111-121.

278. Berger, C.N.; Sodha, S.V.; Shaw, R.K.; Griffin, P.M.; Pink, D.; Hand, P.; Frankel, G. Fresh fruit and vegetables as vehicles for the transmission of human pathogens. Environ. Microbiol. 2010, 12, 2385-2397. [CrossRef]

279. Heiman, K.E.; Mody, R.K.; Johnson, S.D.; Griffin, P.M.; Gould, L.H. Escherichia coli O157 outbreaks in the United States, $2003-2012$. Emerg. Infect. Dis. 2015, 21, 1293. [CrossRef]

280. Wadamori, Y.; Gooneratne, R.; Hussain, M.A. Outbreaks and factors influencing microbiological contamination of fresh produce. J. Sci. Food Agric. 2017, 97, 1396-1403. [CrossRef] [PubMed]

281. Gao, H.-X.; He, Z.; Sun, Q.; He, Q.; Zeng, W.-C. A functional polysaccharide film forming by pectin, chitosan, and tea polyphenols. Carbohydr. Polym. 2019, 215, 1-7. [CrossRef]

282. Naeem, A.; Abbas, T.; Ali, T.M.; Hasnain, A. Effect of antioxidant and antibacterial properties of guar gum coating containing spice extracts and its application on tomatoes (Solanum lycopersicum L.). Food Measure 2018, 12, 2725-2734. [CrossRef]

283. Yousuf, B.; Srivastava, A.K. Flaxseed gum in combination with lemongrass essential oil as an effective edible coating for ready-to-eat pomegranate arils. Int. J. Biol. Macromol. 2017, 104, 1030-1138. [CrossRef] [PubMed]

284. Sessa, M.; Ferrari, G.; Donsi, F. Novel edible coating containing essential oil nanoemulsions to prolong the shelf life of vegetable products. Chem. Eng. Trans. 2015, 43, 55-60. [CrossRef]

285. Severino, R.; Ferrari, G.; Vu, K.D.; Donsi, F.; Salmieri, S.; Lacroix, M. Antimicrobial effects of modified chitosan based coating containing nanoemulsion of essential oils, modified atmosphere packaging and gamma irradiation against Escherichia coli O157:H7 and Salmonella typhimurium on green beans. Food Control 2015, 50, 215-222. [CrossRef]

286. Bankura, K.; Maity, D.; Mollick, M.M.; Mondal, D.; Bhowmick, B.; Bain, M.; Chakraborty, A.; Sarkar, J.; Acharya, K.; Chattopadhyay, D. Synthesis, characterization and antimicrobial activity of dextran stabilized silver nanoparticles in aqueous medium. Carbohydr. Polym. 2012, 89, 1159-1165. [CrossRef]

287. Liu, Y.; Chen, S.; Zhong, L.; Wu, G. Preparation of high-stable silver nanoparticle dispersion by Rusing sodium alginate as a stabilizer under gamma radiation. Radiat. Phys. Chem. 2009, 78, 251-255. [CrossRef]

288. Venkatesan, J.; Singh, S.K.; Anil, S.; Kim, S.-K.; Shim, M.S. Preparation, characterization and biological applications of biosynthesized silver nanoparticles with chitosan-fucoidan coating. Molecules 2018, 23, 1429. [CrossRef]

289. Lin, B.; Luo, Y.; Teng, Z.; Zhang, B.; Zhou, B.; Wang, Q. Development of silver/titanium dioxide/chitosan adipate nanocomposite as an antibacterial coating for fruit storage. LWT Food Sci. Technol. 2015, 63, 1206-1213. [CrossRef]

290. Bahrami, A.; Mokkarram, R.R.; Khiabani, S.M.; Ghanbarzadeh, B.; Salehi, R. Physico-mechanical and antimicrobial properties of tragacanth/hydroxypropyl methylcellulose/beeswax edible films reinforced with silver nanoparticles. Int. J. Biol. Macromol. 2019, 129, 1103-1112. [CrossRef]

291. Mohammed Fayaz, A.; Balaji, K.; Girilal, M.; Kalaichelvan, P.T.; Venkatesan, R. Mycobased Synthesis of Silver Nanoparticles and Their Incorporation into Sodium Alginate Films for Vegetable and Fruit Preservation. J. Agric. Food Chem. 2009, 57, 6246-6252. [CrossRef]

292. Khalaf, H.H.; Sharoba, A.M.; El-Tanahi, H.H.; Morsy, M.K. Stability of antimicrobial activity of pullulan edible films incorporated with nanoparticles and essential oils and their impact on turkey deli meat quality. J. Food Dairy Sci. 2013, 4, 557-573. [CrossRef]

293. EU Circular Economy Action Plan. A New Circular Economy Action Plan for a Cleaner and More Competitive Europe. Available online: https:/ / ec.europa.eu/environment/circular-economy/index_en.htm (accessed on 17 January 2021).

294. Bou-Mitri, C.; Abdessater, M.; Zgheib, H.; Akiki, Z. Food packaging design and consumer perception of the product quality, safety, healthiness and preference. Nutr. Food Sci. 2020. ahead-of-print. [CrossRef]

295. Vila-Lopez, N.; Küster-Boluda, I. A bibliometric analysis on packaging research: Towards sustainable and healthy packages. Br. Food J. 2020. ahead-of-print. [CrossRef]

296. Chawla, R.; Sivakumar, S.; Kaur, H. Antimicrobial edible films in food packaging: Current scenario and recent nanotechnological advancements-A review. Carbohydr. Polym. Technol. Appl. 2021, 2, 100024. [CrossRef]

297. Van Crevel, R. Bio-Based Food Packaging in Sustainable Development. Food and Agriculture Organization of the United Nations. 2016. Available online: http:/ / www.fao.org/forestry/45849-023667e93ce5f79f4df3c74688c2067cc.pdf (accessed on 10 February 2021).

298. Rijk, R.; Veraart, R. (Eds.) Global Legislation for Food Packaging Materials; John Wiley \& Sons: Hoboken, NJ, USA, 2010; Available online: https:/ / www.worldpackaging.org/Uploads/SaveTheFood/GlobalLegislationFoodPackagingMaterials.pdf (accessed on 10 February 2021). 
299. Motelica, L.; Ficai, D.; Ficai, A.; Oprea, O.C.; Kaya, D.A.; Andronescu, E. Biodegradable Antimicrobial Food Packaging: Trends and Perspectives. Foods 2020, 9, 1438. [CrossRef] [PubMed]

300. Wu, Y.M.; Wang, Z.W.; Hu, C.Y.; Nerín, C. Influence of factors on release of antimicrobials from antimicrobial packaging materials. Crit. Rev. Food Sci. Nutr. 2018, 58, 1108-1121. [CrossRef] [PubMed]

301. Jeya, J.; Chandrasekaran, M.; Venkatesan, S.P.; Sriram, V.; Britto, J.G.; Mageshwaran, G.; Durairaj, R.B. Scaling up difficulties and commercial aspects of edible films for food packaging: A review. Trends Food Sci. Technol. 2020, 100, 210-222. [CrossRef]

302. Guilbert, S.; Gontard, N.; Cug, B. Technology and application of edible protective films. Packag. Techol. Sci. 1995, 8, 339-346. [CrossRef]

303. Ribeiro-Santos, R.; Andrade, M.; de Melo, N.R.; Sanches-Silva, A. Use of essential oils in active food packaging: Recent advances and future trends. Trends Food Sci. Technol. 2017, 61, 132-140. [CrossRef]

304. Kraśniewska, K.; Gniewosz, M. Substances with antimicrobial activity in edible films-A review. Pol. J. Food Nutr. Sci. 2012, 62, 199-206. [CrossRef]

305. Espitia, P.J.P.; Du, W.X.; Avena-Bustillos, R.J.; Soares, N.F.; McHugh, T.H. Edible films from pectin: Physical-mechanical and antimicrobial properties-A review. Food Hydrocoll. 2014, 35, 287-298. [CrossRef]

306. Chen, H.M.; Yan, X.J.; Wang, F.; Xu, W.F.; Zhang, L. Assessment of the oxidative cellular toxicity of a k-carrageenan oxidative degradation product towards Caco-2 cells. Food Res. Int. 2010, 43, 2390-2401. [CrossRef]

307. Liu, J.; Zhan, X.; Wan, J.; Wang, Y.; Wang, C. Review for carrageenan-based pharmaceutical biomaterials: Favourable physical features versus adverse biological effects. Carbohydr. Polym. 2015, 121, 27-36. [CrossRef] [PubMed]

308. Prajapati, V.D.; Maheriya, P.M.; Jani, G.K.; Solanki, H.K. Carrageenan: A natural seaweed polysaccharide and its applications. Carbohydr. Polym. 2014, 105, 97-112. [CrossRef]

309. Tobacman, J.K. Review of harmful gastrointestinal effects of carrageenan in animal experiments. Environ. Health Perspect. 2001, 109, 983-994. [CrossRef] 